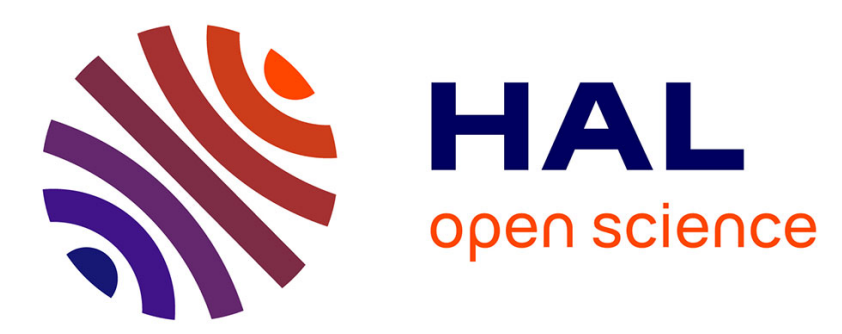

\title{
Recent Advances in the Development of Organic and Organometallic Redox Shuttles for Lithium-Ion Redox Flow Batteries
}

Thuan-nguyen Pham-truong, Qing Wang, Jalal Ghilane, Hyacinthe Randriamahazaka

\section{To cite this version:}

Thuan-nguyen Pham-truong, Qing Wang, Jalal Ghilane, Hyacinthe Randriamahazaka. Recent Advances in the Development of Organic and Organometallic Redox Shuttles for Lithium-Ion Redox Flow Batteries. ChemSusChem, 2020, 13 (9), pp.2142-2159. 10.1002/cssc.201903379 . hal-02999634

\section{HAL Id: hal-02999634 \\ https://hal.science/hal-02999634}

Submitted on 12 Nov 2020

HAL is a multi-disciplinary open access archive for the deposit and dissemination of scientific research documents, whether they are published or not. The documents may come from teaching and research institutions in France or abroad, or from public or private research centers.
L'archive ouverte pluridisciplinaire HAL, est destinée au dépôt et à la diffusion de documents scientifiques de niveau recherche, publiés ou non, émanant des établissements d'enseignement et de recherche français ou étrangers, des laboratoires publics ou privés. 


\title{
Recent advances in development of organic and organometallic redox shuttles for lithium-ion redox flow batteries
}

\author{
Thuan-Nguyen Pham-Truong ${ }^{[\mathrm{b}]}$, Qing Wang ${ }^{[\mathrm{c}]}$, Jalal Ghilane ${ }^{\star[\mathrm{a}]}$ and Hyacinthe Randriamahazaka ${ }^{*[\mathrm{a}]}$
}

\begin{abstract}
In the recent years, redox flow batteries (RFBs) and derivatives have attracted a wide attention from academia to industrial world because of their ability to accelerate large-grid energy storage. Even though the vanadium based RFBs are commercially available, they possess a low energy and power density that might limit their use in further industrial scale. Seeking for improving the performance of RFBs is still an open field for research and development. Herein, a combination between a conventional Li-ion battery and a redox flow battery results in a significant improvement in terms of energy and power density alongside with higher safety and lower cost. Currently, lithium-ion redox flow batteries are becoming a well-established sub-domain in the field of flow battery. Accordingly, design of novel redox mediators with controllable physical chemical characteristics is crucial for bossting this technology to industrial applications. This review summarizes the recent works devoted to the development of novel redox mediators in lithium-ion redox flow batteries.
\end{abstract}

\section{Introduction}

Sustainable development requires massive investment for exploration and utilization of renewable energy sources in the energy balance. Among various forms, electricity is undoubtedly the most desirable energy input for daily uses. For example, in the United States, 4 pentawatt hours (PWh) of electricity were consumed in 2018 while the equivalence in electricity by annual solar energy is found to be 2000 PWh. However, due to the intermittence of the current renewable sources, the electricity must be stored under other forms in order to correlate the fleeting production and the continuous consumption. Furthermore, in order to have a maximum conversion efficiency from the renewable sources to chemical energy, the storage devices need to be capable for fast charging and they need to release a stable, controllable electricity output for a reasonable time - scale.

First appeared in the Early-19 $9^{\text {th }}$ century, battery technologies,

\footnotetext{
[a] Dr. J. Ghilane; Prof. H. Randriamahazaka

SIELE group, ITODYS Lab. - CNRS UMR 7086, Department of

Chemistry, Université de Paris

15 rue Jean Antoine de Baif, 75205 Paris Cedex 13, France

E-mail: hyacinthe.randria@u-paris.fr

[b] A/Prof. T.N. Pham-Truong

Physicochemical Laboratory of Polymers and Interfaces (LPPI EA2528), Department of Chemistry, CY Cergy Paris Université 5 mail Gay Lussac, Neuville sur Oise, 95031 Cergy - Pontoise

[c] A/Prof. Qing Wang

Department of Materials Science and Engineering, National

University of Singapore

Blk. E2, \#05-27, 5 Engineering Drive 2, Singapore 117579
}

especially lithium - ion batteries, ${ }^{[1-5]}$ have been widely investigated and developed to store energy by means of electrochemical reactions. Even though they have significantly contributed to the development of portable technologies and to everyday life, their drawbacks seem to be highly important (explosion, toxic waste, leakage, etc.) ${ }^{[6-9]}$ Consequently, their implication in large-scale energy storage is still limited.

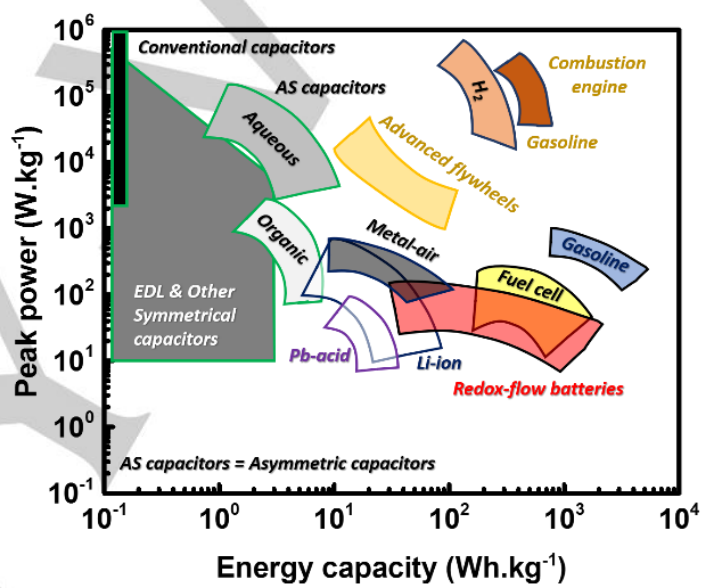

Figure 1. Ragone plot of different energy storage technologies.

However, we did not need to wait for long time to switch from the challenges to opportunities by developing new battery technology, so-called flow battery which is referred to the liquid electrolyte circulating inside the battery. This technology stands on the energy difference between the oxidized/reduced states of certain compounds or elements to store and to deliver energy. As displayed in the figure 1 , even though redox flow battery provides low power density, this technology could offer very high energy density which is suitable for stationary energy storage. They can be divided into three main families: redox flow batteries (most common), hybrid flow batteries and membrane less flow batteries. ${ }^{[10-12]}$ These latter could satisfy several criteria, such as reaching a high power and energy density, safety for large - scale storage, environmental benignity and low cost.

Despite the presence of commercial redox flow systems, seeking for new materials and new approaches for getting more efficient systems is still in progress and also attracts a wide attention from scientific community. Indeed, numerous parameters need to be considered, such as the redox potential, the electron transfer kinetic, the mass transport properties and to some extend solubility and solvation of the redox mediators.

\subsection{A brief history of flow batteries}


Even though it is largely admitted that the very first flow batteries were developed by NASA with the Fe/Ti system in the $1970 \mathrm{~s}^{[13]}$, the earliest RFB is actually belongs to a French military engineer, Charles Renard and his colleague, Arthur Constantin Krebs. Indeed, in 1884, a $959 \mathrm{lb}(435 \mathrm{~kg})$ - Zinc/Chlorine flow battery was used to power a 170 - foot $(52 \mathrm{~m})$ long airship, La France ${ }^{[14]}$ Seventy years later, Posner ${ }^{[15]}$ proposed a redox flow battery based on the difference of potential $(>0.8 \mathrm{~V})$ between $\mathrm{Fe}^{3+} / \mathrm{Fe}^{2+}$ or $\mathrm{Br}_{2} / \mathrm{Br}^{-}$and $\mathrm{Sn}^{4+} / \mathrm{Sn}^{2+}$. Since then, the redox flow battery's field started to be recognized as promising solution for large - scale energy storage. Consequently, NASA got into the field in the early 1970s and released their first report in 1977 via the NASA-TM-79067 (DOE/NASA/1002-78/2) program. ${ }^{[16]}$ In the continuation of this fancy work, several projects had been done (NASA TM-81464, ${ }^{[17]}$ NASA TM-82607,${ }^{[18]}$ NASA CR-167882,${ }^{[19]}$ NASA TM-82686, ${ }^{[20]}$ NASA TM-82940, ${ }^{[21]}$ NASA TM-83401 ${ }^{[22]}$ ) by considering several redox couple screenings. Also, they had been coupled to other energy - driven systems like solar cells. Unfortunately, due to significant drawbacks, such as crossover reactions and low coulombic efficiency. At this period, the RFBs were not further considered as a good option for energy storage. When one door closes, another opens; Skyllas-Kazacos and her colleagues at University of New South Wales was successfully able to launch an all-vanadium redox flow battery, which is based on the multi-redox states of vanadium in aqueous media. ${ }^{[23]}$ The main advantage of this new design consists to provide much larger energy capacity only by increasing the size of electrolyte reservoirs. The battery could have an energy density of $25 \mathrm{Wh} \cdot \mathrm{kg}^{-1}$, a depth of discharge (DoD) of $90 \%$ which is outstanded compared to others available batteries. Furthermore, the water - based electrolyte is safer, noninflammable and more stable (negligible degradation over 1500 hours). Also, the crossover does not severely damage the system. This concept and achievements were patented in 1986 under the name of NSWU. ${ }^{[24-26]}$ Since then, a mass investigation has been launched to optimize/ improve the performance and the stability of this type of battery. ${ }^{[27-31]}$ However, up-to-date, the energy density of vanadium - based batteries is still far lower than Li-ion battery $\left(80-200 \mathrm{Wh} . \mathrm{kg}^{-1}\right)$ due to the limit of solubility of vanadium ions in water. Nevertheless, numerous companies have been involved in development and commercialization of $\mathrm{V}$ - based RFB, typically as Enerox GmbH (Austria), UniEnergy Technologies (USA), Sumitomo (Japan), Australian Vanadium (Australia), Rongke Power (China), etc. In parallel with VFB, the recent years have witnessed an arise in development of organic/inorganic flow batteries ${ }^{[32-35]}$ or of all-organic flow batteries. ${ }^{[36-39]}$ Indeed, the use of organic based materials can solve several metal related problems, e.g. the toxicity of heavy metals. Furthermore, this approach could lead to cost efficient, eco-friendly, high performant redox flow systems that are suitable for large - scale energy storage.

\subsection{Different types of redox shuttles}

Since the first investigation of redox flow battery system, numerous redox couples have been tested in RFB configuration. In complement of commercially available redox mediators, synthetized ones have also been prepared with precise physical chemical properties that allow improving either the performance of the batteries or favouring large - scale energy storage systems. In brief, all the redox molecules could be classified in three main categories: inorganic, organic and organometallic compounds.

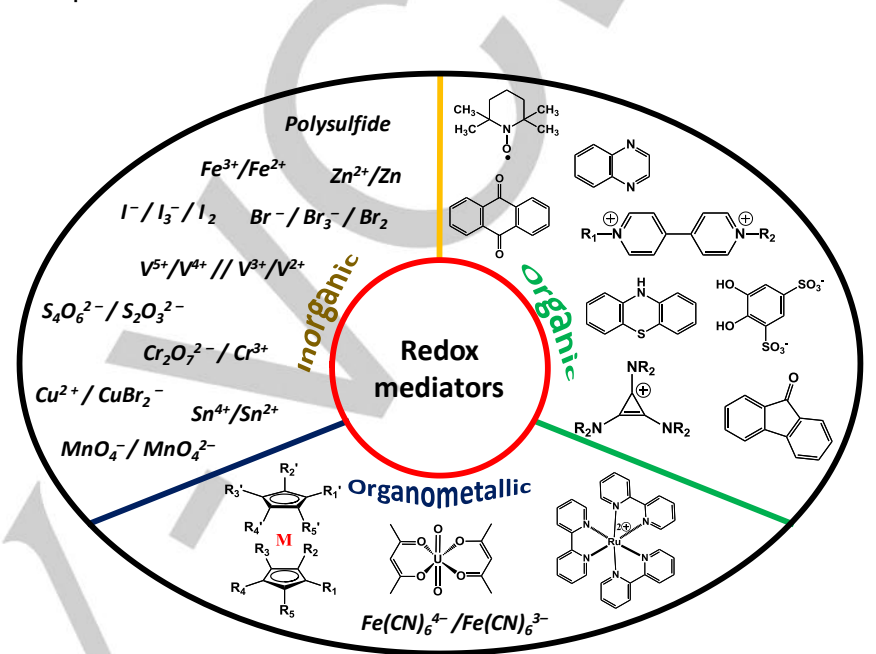

Figure 2. Typical structure redox mediators for redox flow batteries which were reported in the literature

Inorganic redox mediators could provide a strong stability in aqueous solutions with reasonable cell voltage. Typical redox couples can be listed as $\mathrm{Fe}^{3+} / \mathrm{Fe}^{2+}\left(\mathrm{E}^{0}=0.771 \mathrm{~V}\right), \mathrm{Cu}^{2+} / \mathrm{Cu}^{+}\left(\mathrm{E}^{0}=\right.$ $0.159 \mathrm{~V}), \mathrm{Cu}^{2+} / \mathrm{CuBr}_{2}^{-}\left(\mathrm{E}^{0}=0.520 \mathrm{~V}\right), \mathrm{Sn}^{4+} / \mathrm{Sn}^{2+}\left(\mathrm{E}^{0}=0.771 \mathrm{~V}\right)$, $\mathrm{Br}_{2} / \mathrm{Br}^{-}\left(\mathrm{E}^{0}=1.087 \mathrm{~V}\right), \mathrm{Br}_{3}{ }^{-} / \mathrm{Br}^{-}\left(\mathrm{E}^{0}=1.050 \mathrm{~V}\right), \mathrm{S}_{4} \mathrm{O}_{6}{ }^{2-} / \mathrm{S}_{2} \mathrm{O}_{3}{ }^{2-}$ $\left(\mathrm{E}^{0}=0.08 \mathrm{~V}\right)$. All of the standard potentials are reported versus SHE. However, the number of choices is limited by the number of transition metals and by the number of counterions. Furthermore, some of them are not stable in water solution (e.g. Sn ions) or are located beyond the acceptable voltage range which is limited by water oxidation $(1.23 \mathrm{~V})$. Besides, side reactions might cause major problems, i.e. deposition of metallic $\mathrm{Cu}$ or $\mathrm{MnO}_{2}$, which decreases the cell voltage and damages the current collectors. In short, promising systems lie on a more restricted range of species, e.g. the use of $\mathrm{Fe}$, vanadium, bromine, iodine, polysulfide.

In complement with inorganic compounds, organic molecules have been demonstrated to be promising system that can work in both organic and aqueous media. A main advantage of this family is related to a flexible elaboration with the chemical physical properties via modulation of the chemical structure. For example, a massive investigation has been given to develop anthraquinone derivatives by changing the substituents. It was proven by Aziz's group that the functionalization of anthraquinone by electron donating effect (e.g. hydroxyl) could lead to lower the standard potential of the quinone functions, ${ }^{[40]}$ 
resulting in a cell voltage of $1.2 \mathrm{~V}$ for $2,6-\mathrm{DHAQ} /$ ferrocyanide system. Later, by substituting the 2,6 - DHAQ with two hydroxyl group at position $C(3)$ and $C(7)$, a significant gain in cell voltage was observed $\left(\mathrm{V}_{\text {cell }}=1.3 \mathrm{~V}\right)$. Besides, the presence of $-\mathrm{OH}$ groups increases the solubility of the 2,6 - DHAQ in alkaline solution (> $0.6 \mathrm{M}$ in $1 \mathrm{M} \mathrm{KOH}$ ). In the continuation of this work, the hydroxyl groups were replaced by sulfonate groups, resulting to 1,4-dihydroxyanthraquinone- 2,3-dimethylsulfonic acid (DHAQDMS) which provide a gain of $>200 \mathrm{mV}$ in standard potential compared to AQDS. The solubility of this compound in water was enhanced ( $>1 \mathrm{M}$ in $3 \mathrm{M}$ proton). Even though there is a good potential of application for AQ-based RFB, the DHAQ suffers a degradation over cycling where a dimerization was demonstrated, that lower the capacitance over time. ${ }^{[41]}$ To further increase the solubility of $A Q$ derivatives, i.e. the energy density, B. Hu et al. ${ }^{[42]}$ proposed to use $\mathrm{NH}_{4}{ }^{+}$as counter ions for AQDS instead of proton or $\mathrm{Na}^{+}$. Interestingly, the AQDS $\left(\mathrm{NH}_{4}\right)_{2}$ exhibits a strong enhancement in solubility in water (1.9 M compared to $0.58 \mathrm{M}$ for $\mathrm{AQDSNa}$ ). The synthetized molecule was applied to a neutral $\mathrm{pH}$, resulting to a cell voltage of $0.8 \mathrm{~V}$, an energy

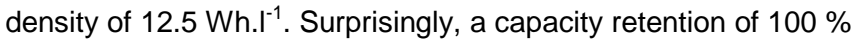
over one month was obtained, which indicates that the dimerization is somehow inhibited with this type of structure. As displayed in the figure 3 , the computational description of the influence of substituents on the electronic/ electrochemical properties of quinone compounds. ${ }^{[43]}$
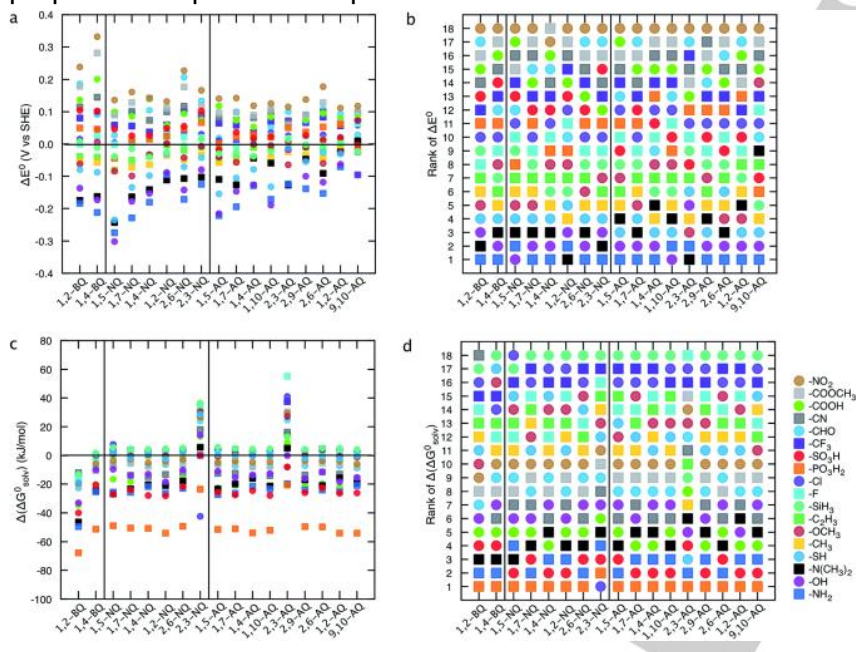

Figure 3. Computational calculation of the influence of substituents on the electrochemical behaviors of quinone derivatives ${ }^{[43]}$.

In addition to quinone derivatives, other families of redox molecules have also been studied, such as, polyaniline (PANI) ${ }^{[44,45]}$ polythiophene, ${ }^{[46]}$ viologen derivatives, ${ }^{[47,48]} 2,2,6,6$ tetramethylpiperidine-1-oxyl (TEMPO), ${ }^{[49-51]}$ alkoxybenzenebased molecules, ${ }^{[52]}$ etc.

Profiting the possibility to modulate the physical chemical properties of organic molecules and the stability of inorganic compounds, organometallic mediators appear as good candidate for redox flow battery systems. The first member of this family entered in the RFB's field was introduced by A. Bard and al. $^{[53]}$ at UT at Austin, USA, namely Iron (III) - Iron (II) Complexes with $\mathrm{O}-\mathrm{Phenanthroline}\left(\mathrm{E}^{0}=0.8 \mathrm{~V}\right.$ vs. $\left.\mathrm{SCE}\right)$. Later, ferrocyanide $\left(\mathrm{Fe}(\mathrm{CN})_{6}{ }^{3-} / \mathrm{Fe}(\mathrm{CN})_{6}{ }^{4-}, 0=0.361\right.$ vs. $\left.\mathrm{SHE}\right)$ was widely used in RFB configuration (posolyte) because of its chemical stability and appropriate standard potential..$^{[54-56]}$ Nevertheless, the most known sub-family of organometallic is metallocene derivatives, e.g. ferrocene, cobaltocene. G. Yu et al. introduced ferrocene in RFB in 2014, where the system generate a power density of $120 \mathrm{Wh} . \mathrm{kg}^{-1}$ and a specific capacity of $130 \mathrm{~mA} . \mathrm{h} . \mathrm{g}^{-1}{ }^{[57]}$ Later, all-metallocene redox flow battery was introduced by Hwang et al. ${ }^{[58]}$ and G. Yu's et al. ${ }^{[59]}$ in which the ferrocene and the cobaltocene were used as the catholyte and anolyte, respectively. In this work, the concentration of the redox species is as high as $1.5 \mathrm{M}$, leading to a higher energy density when compared to other molecules. Finally in this configuration the cell voltage is about $1.7 \mathrm{~V}$ which could be upgraded to $2.1 \mathrm{~V}$ when using decamethylcobaltocene redox molecule.

\subsection{Development and progress of Lithium - ion Redox flow batteries}

In 2011, a brand-new concept was firstly reported by Goodenough' s group (UT at Austin, USA) ${ }^{[60-62]}$ and followed up by Zhou's group (AIST, Japan). ${ }^{[63,64]}$ The later consists to combine a conventional lithium-ion battery and a redox flow system affording the first $\mathrm{Li}$ - based redox flow battery system. Briefly, the reactions at both sides can be described as followed:

Anode $: n M \rightarrow n M^{+}+n e^{-}$

Cathode: $R^{z+}+n e^{-} \rightarrow \mathrm{R}^{(z-n)+}$

Where $\mathrm{M}$ is alkali-metals (i.e. $\mathrm{Li}$ or $\mathrm{Na}$ ), $\mathrm{R}$ represents the redox species, $z$ is its initial charge and $n$ is the number of required electrons to oxidize/reduce one molecule of $\mathrm{R}(1 \leq \mathrm{n}<\mathrm{z})$. Consequently, this approach allows to go beyond the limit of solubility at the anode side, thus increases the energy density. The first reported battery produces $17.1 \mathrm{~mW} . \mathrm{cm}^{-2}$ as power density. [Erreur! Signet non défini.] However, the major drawback of this technique is related to the complexity of the system where an appropriate solid electrolyte separator between an aqueous cathode and organic electrolyte on the anode side is mandatory.

Two years later, a different approach was proposed by Wang et al. ${ }^{[65]}$ that preliminarily allows to break the boundary for liquid and solid energy storage, i.e. reversible chemical delithiation/lithiation of $\mathrm{LiFePO}_{4}$ (LFP). Later, a new concept of redox-targeting redox flow battery was reported by the same group. ${ }^{[66]}$ A schematic representation of this Lithium-ion redox targeting redox flow battery is illustrated in the figure 4 . Precisely, two adequate redox mediators were chosen to carry charges in each reservoir. An appropriate couple of redox shuttles must satisfy at least one condition: one molecule needs to have higher standard potential than the Li-storage material, i.e. having capability to oxidize/reduce the solid material during 
charging process while the other one must have a lower standard potential that allows carrying back the given charges during discharging process. As a proof-of-concept, at the anode side, ferrocene $\left(\mathrm{E}^{0}=3.4 \mathrm{~V} / \mathrm{Li}^{+} \mid \mathrm{Li}\right)$ and dibromoferrocene $\left(\mathrm{E}^{0}=\right.$ $\left.3.78 \mathrm{~V} / \mathrm{Li}^{+} \mid \mathrm{Li}\right)$ were chosen for transferring charges from the $\mathrm{EC}$ cell to the reservoir $\left(\mathrm{LiFePO}_{4}\right.$ as solid material $\left(\mathrm{E}^{0}=3.45 \mathrm{~V} /\right.$ $\left.\mathrm{Li}^{+} \mid \mathrm{Li}\right)$ ). During the charging process, the $\mathrm{FCBr}_{2}$ is oxidized in the cell and is transferred to the tank where a chemical delithiation occurred based on a difference in potential $\left(\Delta \mathrm{E}^{0}=0.33 \mathrm{~V}\right)$ as driven force. This reaction results in generation of $\mathrm{Li}$-ion, $\mathrm{FePO}_{4}$ and in regeneration of $\mathrm{FcBr}_{2}$. The cycle is looped until a complete consumption of the LFP material. For the discharging process, $\mathrm{Fc}$ is generated which allows to reduce $\mathrm{FePO}_{4}$ to LFP (lithiation) by a difference of potential $\left(\Delta \mathrm{E}^{0}=0.05 \mathrm{~V}\right)$. Similar phenomenon occurs in the cathode side where cobaltocene and decamethylcobaltocene were used to charge/discharge $\mathrm{TiO}_{2}$. The concentration of $\mathrm{Li}$ inside the solid materials is $22.8 \mathrm{M}$ for $\mathrm{LiFePO}_{4}$ and $22.5 \mathrm{M}$ for $\mathrm{Li}_{0.5} \mathrm{TiO}_{2}$, the obtained volumetric energy density is $238 \mathrm{Wh}^{-\mathrm{I}^{-1}}$ which is 5 times greater than conventional RFBs.

Regardless of promising performance, obvious limitations of this technology can be listed as the dependence of power density to the solubility of the redox mediator and the significant voltage loss due to a difference in standard potentials of redox shuttles. Based on the same concept, several advancements have been made to minimize and/or to resolve the aforementioned problems, ${ }^{[67-69]}$ e.g. use of $\mathrm{I}_{3}{ }^{-} / \mathrm{I}_{2} / \mathrm{I}^{-}$as a bi-redox molecule which allows targeting the redox potential of $\mathrm{LiFePO}_{4}\left(\sim 370\right.$ Wh. $\mathrm{kg}^{-1}$ and $\sim 670 \mathrm{Wh} . \mathrm{L}^{-1}$ at $50 \%$ porosity of solid material). The resulted performance overcomes current commercially available $\mathrm{Li}$-ion batteries and is 10 times greater than all - vanadium RFBs $\left(50\right.$ Wh. L $\left.^{-1}\right){ }^{[70]}$

Derived from the reported concepts by Goodenough's, Zhou's and Wang's group investigated several redox mediators that fit the Li-ion RFB configuration which is potentially promising to replace VFBs in large - scale energy storage. Within this context, the recent advancements in developing new redox shuttles that allow the improvement of the performance and the long-term stability of Li-ion RFBs will be discussed. It is worth noting that our vision is to reduce the use of metals in the manufacture of the batteries. The use of organic materials permits addressing critical points observed with inorganic systems, such as the structure tuning, low cost material and the higher environmental benignity. The remaining part of this review will focus on the design as well as the physical chemical properties of several categories of organic based molecules used in Li-RFBs.
A

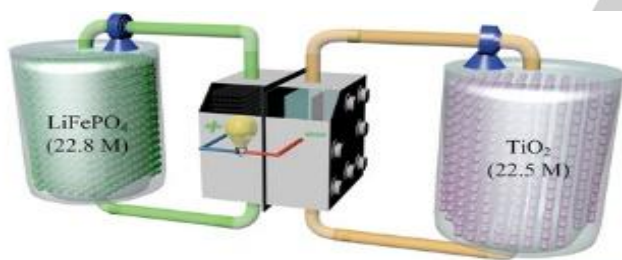

B

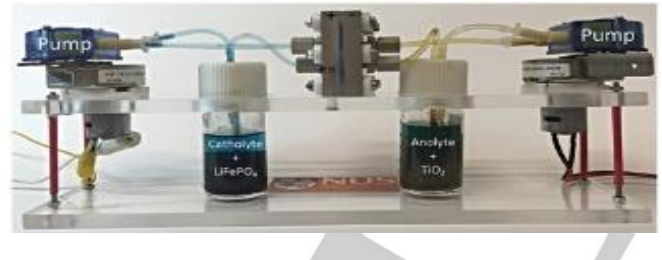

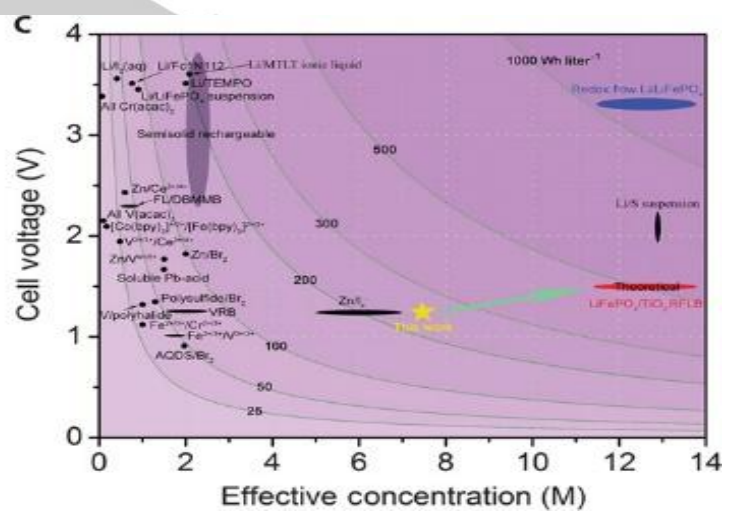

D

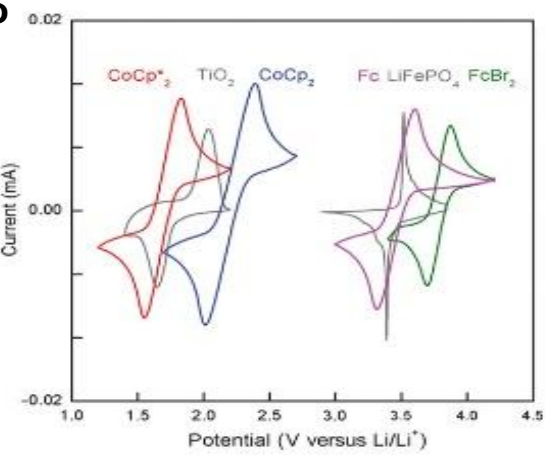

$\mathbf{E}$

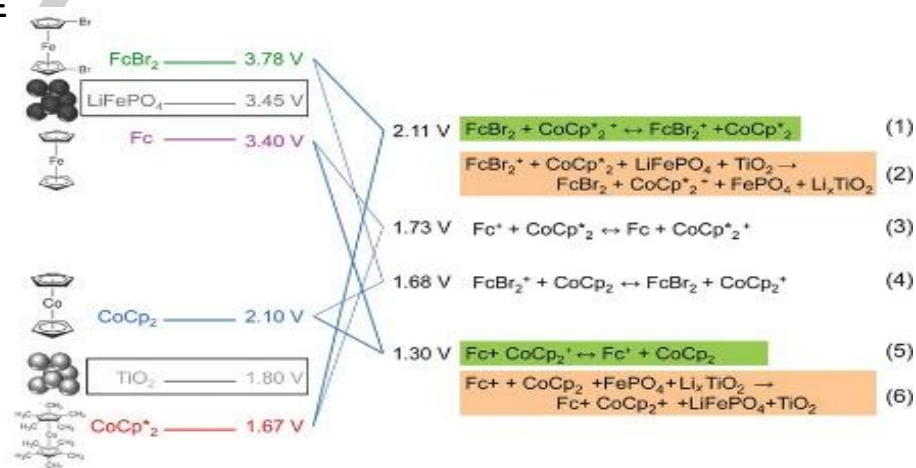

Figure 4. (A) Typical structure of Li-ion redox - targeting redox flow batteries, (B) Photograph of a full cell, (C) reported energy density of various RFB systems in literature, including this work, (D) cyclic voltammograms of redox mediators and Li-based materials and (E) Schematic representation of electrochemical processes in the cell under operation ${ }^{[71]}$. 
For instance, other chemistries have also been explored including the bi-redox electrolytes, artificial bipolar molecules as well as the use of deep eutectic solvents. Typically, Zhu et al. ${ }^{[72]}$ reported the use of 1-(4-ferrocenyl-n-butyl)-1'-[3(trimethylammonio)propyl]-4,4-bipyridinium as artificial bipolar molecules to afford symmetric redox flow battery system. Hence, the cyclability is enhanced up to $75 \%$ in capacity retention after 4000 cycles at $100 \%$ depth of discharge (DoD) with a discharge

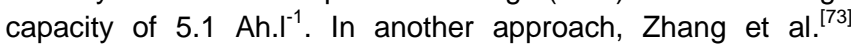
describe the synthesis of bi-redox eutectic electrolyte by combining 1,1-dimethylferrocene and $\mathrm{N}$-butylphthalimide without any further treatment, leading to the formation of a dark red liquid. In term of performance, this electroactive liquid could provide a high power density of $192 \mathrm{~mW} . \mathrm{cm}^{-2}$ and a discharge capacity of $10.1 \mathrm{Ah}^{\mathrm{I}^{-1}}$ at a concentration of $1.0 \mathrm{M}$. In complement with enhanced cycling performance, these families of compound allow to prevent contamination of electrolytes by crossover.

\section{Organic redox shuttles in lithium-ion RFBs}

A wide range of organic molecules are available and could cover

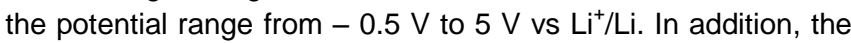
redox potential could be modulated by addition of functional groups, i.e. electron donor or acceptor group. The below subsections describe the 3 main categories of organic compounds: $\mathrm{n}$ - type, $\mathrm{p}$ - type and bipolar molecules.

\section{1. n-type organic shuttles}

The $\mathrm{n}$ - type molecules represent a family of compounds that have the ability to accept electrons. Some of them could be listed as carbonyl, quinone and viologen derivatives. Accordingly, the general cell mechanism is given as followed:

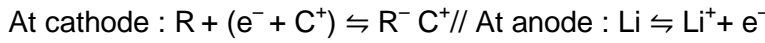

Carbonyl derivatives. Massive research has been focused on developing appropriate molecules bearing carbonyl functional group for Li-ion RFB. With adequate structure, carbonyl groups can undergo reversible reduction reaction, resulting to formation of stable anionic radicals. Indeed, when a carbonyl group is linked to an aromatic ring, resulting to a fully conjugated system. As a result, the received electron can be delocalized by involving in the resonance of the carbon backbone. Typical example of this family of compound is quinone derivatives. Under cathodic polarization, quinone groups are reduced by forming stable monoanionic radical which is followed by formation of di-anionic species if the potential is kept increasing. Furthermore, the good solubility of quinone derivatives in aprotic solutions anticipates their use in these conditions. $\mathrm{H}$. Senoh et al. ${ }^{[74]}$ reported the used of 1,4-benzoquinone (BQ) and 2,5-dialkoxy-1,4benzoquinone derivatives (DMBQ, DEBQ and DPBQ) in a static $\mathrm{Li}$-ion flow battery (Figure 5). The standard potential of $B Q$ is determined at $2.65 \mathrm{~V}$ and $2.83 \mathrm{~V}$ vs $\mathrm{Li}^{+} \mid \mathrm{Li}$. As aforementioned, the substitutions modulate the standard potential of quinone derivatives. Accordingly, the standard potentials of 2,5-dialkoxy1,4-benzoquinone molecules are identified at 2.7 V, 2.7 V, 2.6 V for $D M B Q, D E B Q$ and $D P B Q$, respectively. For charge and discharge curves, a specific capacity of $490 \mathrm{mAh} \cdot \mathrm{g}^{-1}$ was obtained with $\mathrm{BQ}$ system which is close to the expected theoretical value $\left(496 \mathrm{mAh} \cdot \mathrm{g}^{-1}\right)$. However, a significant loss in capacity is detected after 25 cycles (77 \% retention). Surprisingly, they found that the stability is inversely proportional to the concentration of the redox species. The mentioned phenomenon was attributed by the authors to the sublimation of $B Q$, instability of the radical anion as well as the low reactivity of the products. They also suggested that the stability concentration dependency could be suppressed by the introduction of substituents, i.e. alkoxy groups, to the aromatic ring. Accordingly, successful attempts were obtained by using 2,5-Diethoxy and 2,5-Dipropoxy-1,4-benzoquinone (DEBQ and DPBQ) as active material (Figure $5 b$ ). Even though the specific capacity dropped to $250 \mathrm{mAh} . \mathrm{g}^{-1}$ and $232 \mathrm{mAh} . \mathrm{g}^{-1}$, a significant improvement in cycling performance was achieved (> $98 \%$ after 25 cycles). Wang et al. ${ }^{[75]}$ reported the possibility of tailoring the structure of anthraquinone using ethylene glycol. The presence of long ethylene glycol chain induces an improvement of solubility of anthraquinone in propylene carbonate (PC), reaching $0.25 \mathrm{M}$ in $\mathrm{PC}$ containing $1 \mathrm{M}$ of $\mathrm{LiPF}_{6}$ (vs $0.05 \mathrm{M}$ in the most polar electrolytes). As a consequence, the energy density reaches $~ 25$ Wh. $^{-1}$ with an energy efficiency (EE) of $83 \%$ (first 5 cycles) (Figure $5 \mathrm{c}$ ). The EE dropped to $70 \%$ after 10 cycles due to the degradation of the active molecules. As aforementioned, the radical anions and di-anions are not stable for long-term exploitation which might be caused by dimerization or polymerization, i.e. generation of macromolecules and polymer precipitate during cycling. Indeed, the electron transfer/ transport within these aggregates are not well - defined up - to - date. A systematic investigation about quinone systems was given by Ding et al. ${ }^{[76]}$ where they provide a coupled experimental and computational study using different aromatic quinones. It was demonstrated that the LUMO of quinone derivatives decreases (in absolute values) by increasing the size of the conjugated cycle. The latter lowered the cell voltage by using aromatic macrocycle (benzene > naphthalene > anthracene $>2,3$-benzanthracene), resulting from an increasing of electronic donating force. However, due to a difference in gap energy $\left(E_{g}=\right.$ LUMO - HOMO) the stability does not follow the same trend. It had been demonstrated elsewhere by Liang et al. ${ }^{[77]}$ that the aromaticity of the cycles is in charge of the stability of the system. Indeed, when quinone groups are reduced, the enolization takes place to delocalize the negative charge. Accordingly, if the HOMO of the molecule extends out of the molecule by injection of extra-electrons, the backbone of the molecule will be failed to support much negative charges. As a consequence, the radicals are not stable, leading to formation of by-products, e.g. dimers, aggregates, etc. As a result, 9,10phenanthrenequinone $\left(\mathrm{PQ}, \mathrm{E}_{\mathrm{g}}=3.41 \mathrm{eV}\right)$ provides the best capacity utilization ( $80.9 \%$ ) among reported molecules. In terms of performance, $\mathrm{BQ}$ based battery is witnessed a fast degradation (6.5\% after 10 cycles) while NQ and PQ provide a higher stability. Deviated from the computational studies where 
$P Q$ should provide better performance, NQ stands out with more than $99.98 \%$ of capacity retention per cycle and a reachable energy density of $60 \mathrm{Wh} . \mathrm{I}^{-1}$ ( $\mathrm{C}=1.0 \mathrm{M}$ in DMA solution). Recently, Shin et al. ${ }^{[78]}$ reported an arylated quinone as efficient active materials. The use of 2- phenyl-1,4-naphthoquinone (PNQ-1) leads to more stable system having $92 \%$ capacity retention and nearly $100 \%$ coulombic efficiency for 150 cycles.
Even though the capacity is relatively high $\left(\sim 200 \mathrm{mAh} \cdot \mathrm{g}^{-1}\right)$, the reported energy density is quite low at 6 Wh. - $^{-1}$ (150 mM of redox molecules with $\mathrm{C}_{\max }=0.31 \mathrm{M}$ in TEGDME electrolyte). The intensification of capacity compared to aforementioned work might be due to an increase of capacity utilization. Nevertheless, the limitation in solubility lowers the energy density of this system.
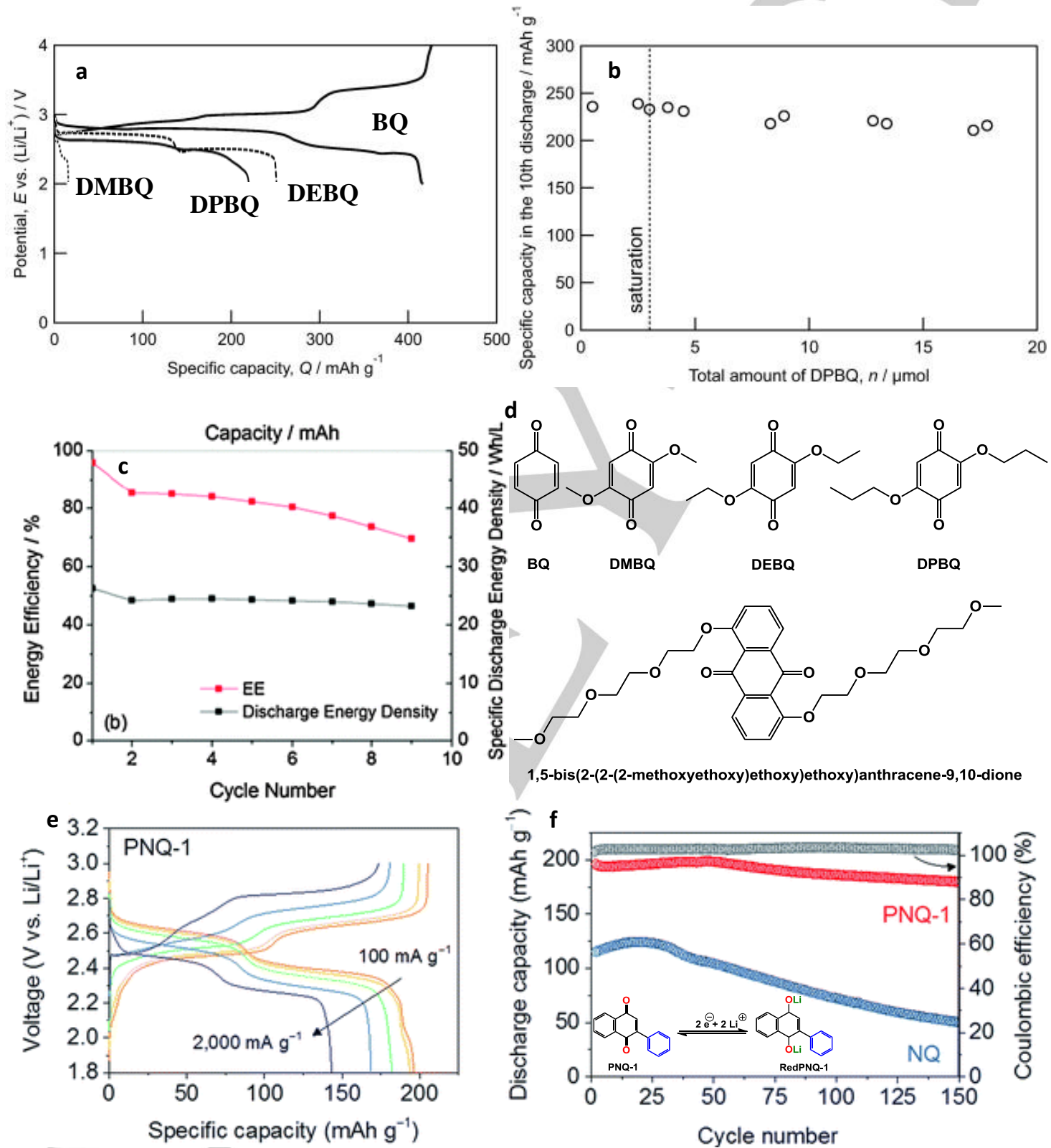

Figure 5. (a) reported charge and discharge curves for 1,4-Benzoquinone (BQ) and discharge curves for 2,5-Dimethoxy-1,4-benzoquinone (DMBQ), 2,5 Diethoxy-1,4-benzoquinone (DEBQ) and 2,5-Dipropoxy-1,4-benzoquinone (DPBQ) and (b) Specific capacity - concentration of DPBQ relationship. ${ }^{[74]}$ The potential range is $2.0-3.4 \mathrm{~V}$ and the charge/discharge current is fixed at $56.5 \mu \mathrm{A}$, (c) Cycling performance of 1,5-bis(2-(2-(2-methoxyethoxy) ethoxy) ethoxy) anthracene-9,10-dione (15D3GAQ) in MORFB configuration, ${ }^{[75]}$ (d) Chemical structure of quinone derivatives used in these studies, (e) and (f) Cycling performance of 2- phenyl-1,4-naphthoquinone ${ }^{[78]}$ 
Overall, different quinone derivatives have been synthetized and evaluated in redox flow batteries. Good candidates have been identified which are 1,4-naphtoquinone derivatives. This family of compounds shows a good compromise between stability, solubility and cycling performance. However, the diffidence in the interpretation of the physical chemical behaviors of all quinone derivatives has made this sub-field in an indistinctive situation. By considering the great potential in development of organic $\mathrm{Li}$ - ion RFBs, some of alternative molecules for carbonyl compounds could be listed as thioethers, aromatic hydrocarbon (anthracene, naphthalene, etc).

\section{Other organic redox molecules}

Quinoxaline. Among different quinoxaline derivatives, triquinoxalinylene exhibits promising characteristics. Matsunaga et al. reported the use of triquinoxalinylenes as cathodes materials, resulting to a large capacity (up to $420 \mathrm{Ah} \cdot \mathrm{kg}^{-1}$ ). ${ }^{[79]}$ Successively, it was claimed that triquinoxalinylene could be reduced by two step electron transfer, involving totally 6 electrons. The first reduction wave was attributed to a fourelectron transfer $(2.36 \mathrm{~V} \mathrm{/} \mathrm{Li}+\mid \mathrm{Li})$ while the second wave corresponded to a two-electron transfer $(2.69 \mathrm{~V} / \mathrm{Li}+\mid \mathrm{Li})$. Accordingly, charge and discharge curves were investigated, resulting to a lower values as cell voltage (1.6 V and $2.3 \mathrm{~V})$. The obtained capacity was determined at $420 \mathrm{Ah}_{\mathrm{kg}}{ }^{-1}$ which is composed of two plateaus (140 Ah. $\mathrm{kg}^{-1}$ and $280 \mathrm{Ah} \cdot \mathrm{kg}^{-1}$ ). Even though remarkable performance was given, some major issues were still remained unsolved, such as the mechanistic pathway for the reduction of a multi-electronic system, the stability of the batteries and the unexpectedly low in cell voltage over cycling. Brushett et al. ${ }^{[37]}$ reported a series of quinoxaline derivatives as anode active material, coupling with 2,5-Di-tert-butyl-1,4-bis(2methoxyethoxy) benzene (DBBB) to afford all-organic Li-ion RFB.

Accordingly, these molecules had been tested in coin - cell configuration, which is non-optimized system. The cell voltage is ranging from $1.8 \mathrm{~V}$ to $2.4 \mathrm{~V}$ when charging and from $1.3 \mathrm{~V}$ to 1.7 during discharge process. Furthermore, as claimed as proof of concept, the performance of the batteries was reported with a
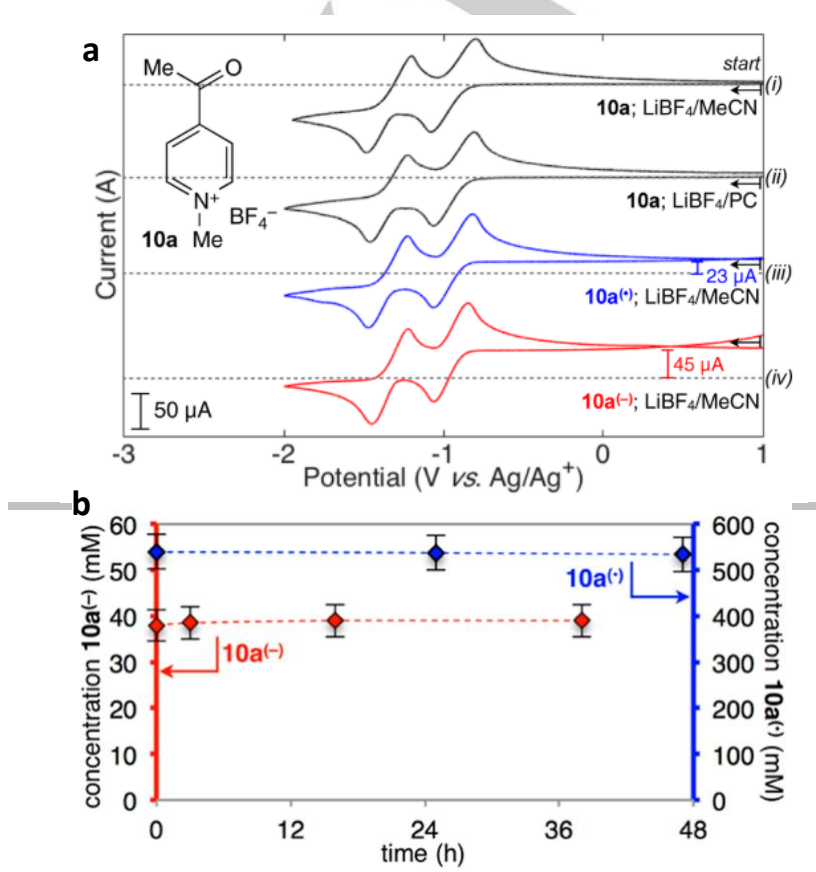

Table 1. Standard potential of different quinoxaline derivatives ${ }^{[37]}$

\begin{tabular}{|c|c|c|}
\hline Molecule & $\begin{array}{c}1^{\text {st }} \text { reduction } \\
\mathrm{E}^{\circ}{\mathrm{Q} / \mathrm{Q}^{-}}^{-}\left(\mathrm{V} / \mathrm{Li}^{+} \mid \mathrm{Li}\right)\end{array}$ & $\begin{array}{c}2^{\text {nd }} \text { reduction } \\
\mathrm{E}^{\circ} \mathrm{Q}^{-{ }^{-}} / \mathrm{Q}^{2-}\left(\mathrm{V} / \mathrm{Li}^{+} \mid \mathrm{Li}\right)\end{array}$ \\
\hline Quinoxaline & $3.07 \pm 0.02$ & $2.649 \pm 0.005$ \\
\hline 2-methylquinoxaline & $2.94 \pm 0.02$ & $2.609 \pm 0.00$ \\
\hline 5-methylquinoxaline & $2.92 \pm 0.02$ & $2.643 \pm 0.004$ \\
\hline 6-methylquinoxaline & $3.04 \pm 0.02$ & $2.609 \pm 0.006$ \\
\hline 2,3-dimethylquinoxaline & $2.85 \pm 0.02$ & $2.525 \pm 0.007$ \\
\hline 2,3,6-trimethylquinoxaline & $2.80 \pm 0.02$ & $2.484 \pm 0.008$ \\
\hline 2,3-diphenylquinoxaline & $3.00 \pm 0.02$ & $2.690 \pm 0.004$ \\
\hline
\end{tabular}

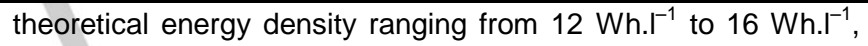
which is limited by the solubility of DBBB in PC and is far lower than state - of - the - art for VFB $\left(40 \mathrm{Wh}^{-l^{-1}}\right)$. Also, the coulombic and the energy efficiency are relatively low, even after an acclimatization time (70 $\pm 4 \%$ and $37 \pm 6 \%$, respectively). Due to several issues as aforementioned, the chemistry of quinoxaline in the field of RFB has not been developed so far. However, the high solubility of quinoxaline derivatives in propylene carbonate (up to $7 \mathrm{M}$ ) could pave the way for high energy density RFB by coupling with suitable p-type molecules.

Alkyl Pyridinecarboxylates derivatives. Recently, Sanford's group reported a workflow for the development of novel chemistry based on alkylpyridinecarboxylates family for Li-ion RFB application. ${ }^{[80]}$

Figure 6. (a) Cyclic voltammograms of $10 \mathrm{a}$ in (i) $\mathrm{MeCN}$, (ii) $\mathrm{PC}$ and of reduced states of $10 \mathrm{a}$ : (iii) $10 \mathrm{a}^{\circ}$, (iv) $10 \mathrm{a}^{-}$in $\mathrm{MeCN}$; (b) Evolution of concentration of $10 \mathrm{a}^{\circ}$ (blue) and $10 \mathrm{a}^{-}$(red) over time. ${ }^{[80]}$

Several generations of molecules have been presented, ranging from free pyridines to isonicotinate and finally to $\mathrm{N}$ - methyl acetylpyridinium $\mathrm{BF}_{4}$ salts (Figure 6). 
The standard potential could be modulated alongside with the chemical structure. Typically, free pyridine derivatives exhibit highly negative standard potential $(>-2 \mathrm{~V} / \mathrm{Ag} \mid \mathrm{AgCl})$ while $\mathrm{N}-$ oxides of isonicotinates have lower values $(-1.4 \mathrm{~V}$ to $-2 \mathrm{~V}$ / $\mathrm{Ag} \mid \mathrm{AgCl})$, Isonicotinates have their standard potential around $1.1 \mathrm{~V} / \mathrm{Ag} \mid \mathrm{AgCl}$. Ultimately, $\mathrm{N}$ - methyl acetylpyridinium $\mathrm{BF}_{4}$ has the first reduction potential at $-0.9 \mathrm{~V} / \mathrm{Ag} \mid \mathrm{AgCl}$. A systematic investigation about the possible pathway for the degradation of the reported molecules was also provided (bond cleavage, dimerization, reaction with water traces, etc.) from which $\mathrm{N}$ methyl acetylpyridinium $\mathrm{BF}_{4}$ is observed to be stable in singly and doubly reduced states with no sign of degradation over days. Furthermore, these molecules can offer an equivalent weight below $150 \mathrm{~g} / \mathrm{mol}^{-} \mathrm{e}^{-}$, which is promising as low molecular weight materials for RFB.

Besides, other chemistries have also been developed based on perylene's ${ }^{[81-83]}$ and naphtalenediimide's structure. ${ }^{[84,85]}$ In summary, $\mathrm{n}$ - type organic molecules have widely investigated, resulting to a large variety of compounds that have been tested in $\mathrm{Li}$ - ion RFB system. Even though they exhibit a promising performance with tailorable physical chemical properties, several issues are still remained open for further studied, including: long term stability, degradation mechanism ${ }^{[86]}$ and electron transfer kinetics.

\section{2. p-type organic shuttles}

The p-type molecules are composed of electron donating compounds (anode: $\mathrm{R} \leftrightharpoons \mathrm{R}^{+}+\left(\mathrm{e}^{-}+\mathrm{A}^{-}\right) / /$cathode: $\left.\mathrm{Li}^{+}+\mathrm{e}^{-} \leftrightharpoons \mathrm{Li}\right)$. $U p$ - to - date, the research in developing p-type compounds is still scanty. Typical examples that were reported in the literature are 1,4-dialkoxybenzene and cyclopropenium salts derivatives.

1,4-dialkoxybenzene derivatives. As reported in the literature, the standard potential of 1,4-dimethoxybenzene is $4.13 \mathrm{~V} / \mathrm{Li}^{+} \mid \mathrm{Li}$ and the value could be modulated from $3.8 \mathrm{~V}$ to $5.9 \mathrm{~V} / \mathrm{Li}^{+} \mid \mathrm{Li}$ by substitutions of electron donating or electron withdrawing groups. Named as the lightest radical cation for charge storage in RFB by Huang et al. ${ }^{[87]}, 1,4-$ dimethoxy-2,5-dimethylbenzene (compound 6) provide a record - breaking intrinsic capacity of 161 mAh. $\mathrm{g}^{-1}$ with a medium - term stability over 100 cycles $(79$ $\%$ energy efficiency and capacity fading rate of $0.2 \%$ per cycle). The charged and discharged voltages are 4.2 and $3.6 \mathrm{~V}$, respectively. Furthermore, the energy density is determined at

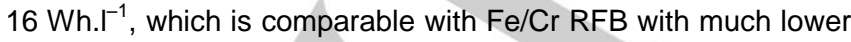
concentration $(0.2 \mathrm{M})$. By changing the substituents, 11 related compounds were tested, resulting in the intrinsic capacity ranging from $79 \mathrm{mAh} . \mathrm{g}^{-1}$ to $194 \mathrm{mAh} \cdot \mathrm{g}^{-1}$ with a significant difference in stability. Having the highest capacity value, the DMOB follows two-step electrochemical oxidation as displayed below:

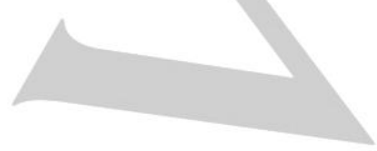

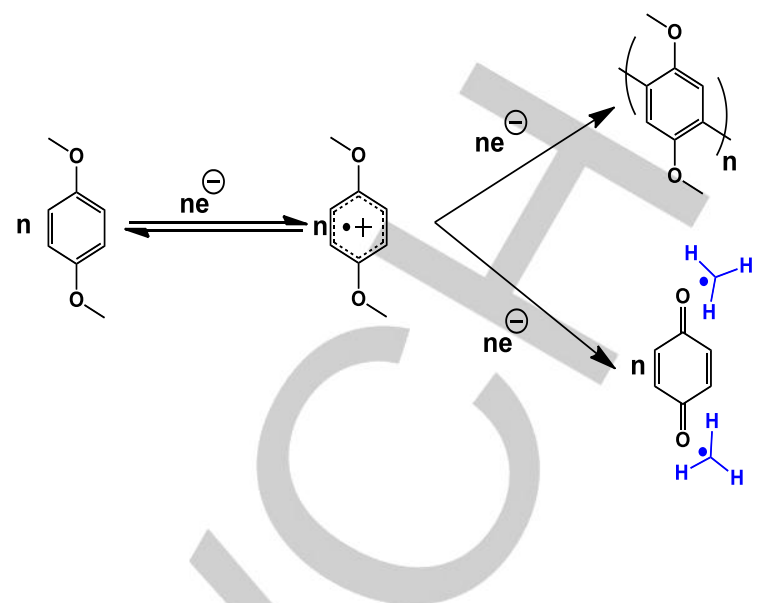

Figure 7. Electrochemical oxidation pathway of DMBB.

The first electron transfer is fully reversible, involving the formation of a stable radical cation while the second oxidation generates unstable intermediates inducing the degradation. From theoretical point of view, this family of molecule could not be used as redox mediator for $\mathrm{Li}$ - ion battery by undergoing irreversible 2 electron - pathway. However, it has been widely reported that the DMOB molecules with different substituents can be used as redox mediator and can help for overcharge protection of $\mathrm{Li}$ - ion batteries. Additional investigations are needed to understand the degradation mechanism.

In the previously mentioned system, ${ }^{[37]}$ 2,5-Di-tert-butyl-1,4bis(2-methoxyethoxy)benzene (DBBB), a redox potential of $\sim 4$ $\mathrm{V} / \mathrm{Li}^{+} \mid \mathrm{Li}$, was coupled with different quinoxaline molecules, resulting to all organic RFB. The DBBB displays an important stability after 200 cycles of $100 \%$ overcharge in a $\mathrm{Li}$ - ion cell (equiv. to 200000 redox cycles). Interestingly, this molecule exhibits the absence of side - products over cycling and is relatively inert in air. However, the poor solubility in EC: EMC electrolyte limits its use as catholyte and results to a very low energy density for the full cell.

Cyclopropenium salts derivatives. A series of cyclopropenium salts was described by Sanford's group, ${ }^{[8]}$ consisting of a 3 member ring cation bearing different $\mathrm{N}$-contained substituents (Figure 8). During oxidation, aminyl radicals are generated, resulting from one electron transfer. Depending on the substituents the standard redox potential is ranged from $0.8 \mathrm{~V}$ to $1 \mathrm{~V} / \mathrm{Fc}^{+} \mid \mathrm{Fc}$, resulting to a high potential catholyte for nonaqueous redox flow batteries. It should be noted that the stability of the radical cation is strongly controlled by the chemical structure of the substituents and the water content in the solution. Only compound 4 and 5 exhibit an exploitable stability over cycling with a coulombic efficiency over $95 \%$ and capacity retention $\sim 100 \%$ after 200 cycles. The stability of the molecules 4 and 5 is an outcome of a steric protection due to the highly ramified amine groups. The latter structure allows localizing the charge in the core side and prevents possible polymerization of the generated radicals. However, the highly branched compound (5) leads to a low solubility of the radical cations $\left(0.081 \mathrm{M}\right.$ for $\left.5^{\circ+}\right)$ 
which lowers the energy density of the battery. The compound 4 represents a good compromise between stability, cyclability and solubility $\left(0.73 \mathrm{M}\right.$ for $4^{*+}$ and $1.7 \mathrm{M}$ for 4$)$.
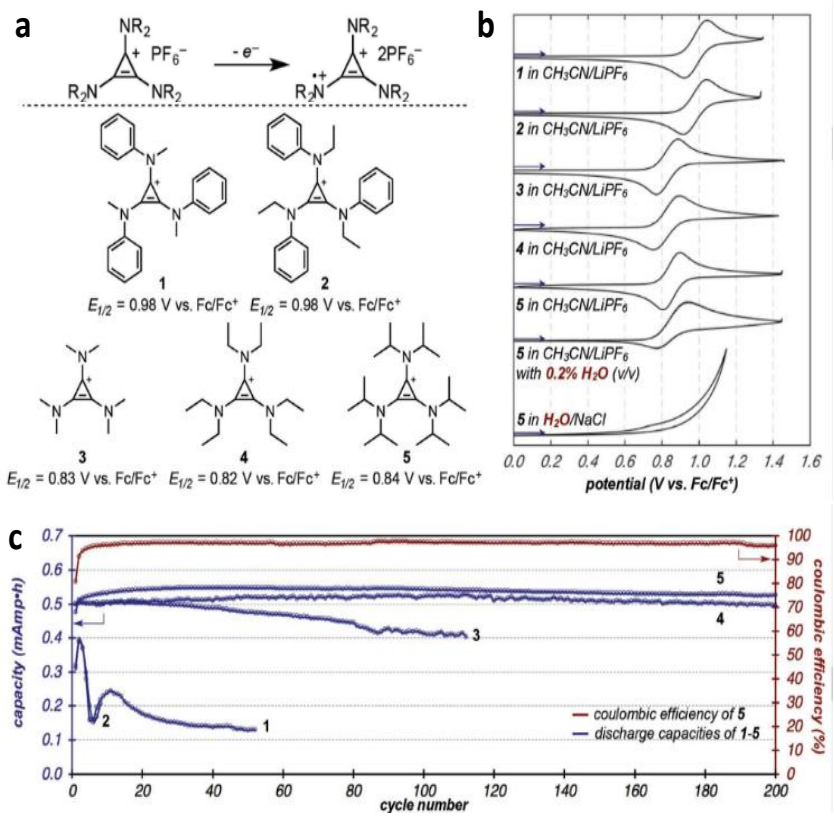

Figure 8. (a) Electrochemical oxidation pathway of cyclopropenium salts, (b) cyclic voltammogram of compound $1-5$ and (c) cycling performance of these compounds. $^{[88]}$

\subsection{Bipolar organic shuttles}

Bipolar molecules refer to a group of compounds that has the ability to accept and to donate electron as followed:

$R^{-}-\left(e^{-}+C^{+}\right) \leftrightharpoons R \leftrightharpoons R^{+}+\left(e^{-}+A^{-}\right)$

where $\mathrm{A}$ and $\mathrm{C}$ represent anion and cation from electrolyte, respectively. From the cell's reactions, it is worth noting that the concentration of supporting electrolyte should be higher. Thus, it could provoke a significant problem where the solubility of supporting electrolyte need to be also improved.

As reported in the literature, nitroxide - based materials are the most studied compounds in redox flow battery systems. Unlike previously repeated problem of stability for $n$ - type and $p$ - type molecules which is due to a large structural rearrangement upon electron transfer events, nitroxide - based compounds have stable structure where electron density is localized in the $\mathrm{N}-\mathrm{O}$ bond, resulting to slightly change in the conformation during oxidation/reduction. The latter implies a strong stability and durability of these materials for battery systems. ${ }^{[89,90]}$ One of the most known nitroxide compounds is 2,2,6,6Tetramethylpiperidin-1-yl)oxyl or (2,2,6,6-tetramethylpiperidin-1yl)oxidanyl (referred as TEMPO). Previously reported works suggests that TEMPO and its derivatives could be reduced to form aminoxy anion and oxidized to oxammonium cation. ${ }^{\left[{ }^{[1-93]}\right.}$ It was reported that the electron transfer rate constant of TEMPO oxidation could reach a value around $0.1 \mathrm{~cm} . \mathrm{s}^{-1},{ }^{[94]}$ which is largely faster when compared to the other organic redox mediators $\left(<10^{-3} \mathrm{~cm} \cdot \mathrm{s}^{-1}\right)$. However, the reduction of TEMPO to TEMPOH remained a slow step where the electron transfer is assigned as quasi-reversible reaction. The latter is caused by proton coupled electron transfer (PCET) process. Consequently, TEMPO and its related molecules are actually used as $p-$ doped compounds by ignoring the electrochemical reduction reaction. In aprotic solvent, e.g. $\mathrm{MeCN}$, the electrochemical oxidation of TEMPO occurs at $0.65 \mathrm{~V} / \mathrm{SCE}$, i.e. $3.94 \mathrm{~V} / \mathrm{Li}^{+} / \mathrm{Li}^{[91]}$ Depending on the composition of the electrolyte solution, the standard redox potential of TEMPO could be ranged from $3.4 \mathrm{~V}$ to $4 \mathrm{~V} / \mathrm{Li}^{+} / \mathrm{Li}$. Other stable nitroxide - radical that are potentially used in battery configuration could be listed as displayed in figure $9 .{ }^{[95,96]}$ As listed, the oxidation potential of nitroxide based molecules is ranged from $3.4 \mathrm{~V}$ to $4.3 \mathrm{~V} / \mathrm{Li}^{+} / \mathrm{Li}$. Even though there is a large choice of structures, only few molecules have been used in $\mathrm{Li}$-ion redox flow batteries. The first demonstration was given by Wei et al. ${ }^{[51]}$ by using TEMPO as catholyte for nonaqueous RFB. The cell was composed of TEMPO/ $1 \mathrm{M} \mathrm{LiPF}_{6} / \mathrm{EC} / \mathrm{PC} / \mathrm{EMC}$ as catholyte and Li metal as anode. The oxidation potential of TEMPO in this configuration is $\sim 3.5 \mathrm{~V} / \mathrm{Li}^{+} / \mathrm{Li}$. At low concentration of active materials, the energy efficiency remained constant at $85 \%$ over 100 cycles and the capacity retention remains at $100 \%$. Furthermore, the TEMPO concentration is linearly proportional to charge time as revealed by electron spin resonance spectroscopy (ESR), indicating that the electrochemical oxidation of TEMPO is fully reversible in $\mathrm{LiPF}_{6} / \mathrm{EC} / \mathrm{PC} / \mathrm{EMC}$ electrolyte.

In the case of concentrated solution $(2.0 \mathrm{M})$, the EE decreases to $\sim 70 \%$ and the delivered energy density of $126 \mathrm{Wh}^{-I^{-1}}$ was obtained. This value is far exceeding the state - of - the art of vanadium RFB. Notwithstanding that more concentrated solution could be possible ( $>5 \mathrm{M}$ ), the generated viscosity would become the major issue where the overall efficiency decreases, i.e. the power of the pump should be much higher. Later, Takeshi et al. ${ }^{[97]}$ reported the use of solvate ionic liquid, constructed from $\mathrm{MeO}$ - TEMPO. Indeed, a mixture of 4-methoxy-2,2,6,6tetramethylpiperidine 1-oxyl (referred as MT or MeO - TEMPO) and lithium bis(trifl uoromethanesulfonyl) imide (LT or LiTFSI) in a $1: 1$ molar ratio, affording a self-melting mixture or solvated redox ionic liquid and could be used as catholyte in RFB. Interestingly, the presence of water does not damage the working performance of the active material. Moreover, the presence of suitable amount of water could decrease the viscosity of the mixture, enabling application in an RFB setup. Precisely, addition of $17 \%$ wt of water to the MTLT 1:1 lowered the viscosity from 10 Pa.s to $72 \mathrm{mPa}$.s. In term of cycling performance, the cell voltage (MTLT $-1: 1+17 \%$ wt of water) is $3.75 \mathrm{~V}$ and $3.6 \mathrm{~V} / \mathrm{Li}^{+} / \mathrm{Li}$ during charge and discharge at 0.1 $\mathrm{mA} . \mathrm{cm}^{-2}$, respectively. An ion - conducting glass ceramics with a thickness of $0.15 \mathrm{~mm}$ was used as membrane. Under the same current density, the charged and discharged capacities were 93 $\%$ and $92 \%$ of theoretical capacity with a good coulombic efficiency of $99 \%$. Even though the capacity retention dropped 
down to $84 \%$ after 20 cycles, outstand energy density was

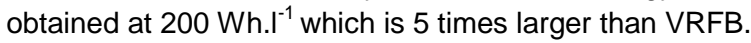

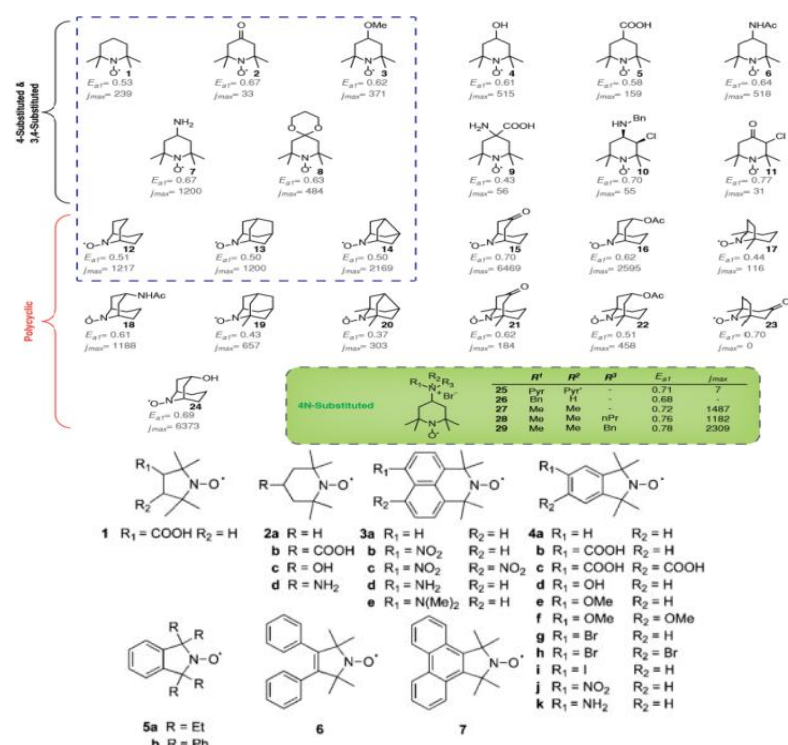

\begin{tabular}{ccccc}
\hline compd & expt1 $E^{\mathrm{o}}$ & corrected to SHE & calcd $E^{a}$ & exptl - calcd \\
\hline $\mathbf{1}$ & 0.702 & 0.976 & 0.971 & 0.005 \\
$\mathbf{2 a}$ & 0.577 & 0.850 & 0.807 & -0.043 \\
$\mathbf{2 b}$ & 0.65 & 0.924 & 0.895 & -0.029 \\
$\mathbf{2 c}$ & 0.603 & 0.877 & 0.836 & -0.041 \\
$\mathbf{2 d}$ & 0.789 & 1.063 & 0.795 & -0.268 \\
$\mathbf{3 a}$ & 0.736 & 1.010 & 0.474 & -0.536 \\
$\mathbf{3 b}$ & 0.822 & 1.096 & $0.572^{b}$ & -0.524 \\
$\mathbf{3 c}$ & 0.902 & 1.175 & $0.705^{b}$ & -0.470 \\
$\mathbf{3 d}$ & 0.829 & 1.102 & $0.341^{b}$ & -0.761 \\
$\mathbf{3 e}$ & 0.908 & 1.182 & $0.474^{b}$ & -0.708 \\
$\mathbf{4 a}$ & 0.771 & 1.045 & 0.999 & -0.046 \\
$\mathbf{4 b}$ & 0.821 & 1.095 & $1.080^{b}$ & -0.015 \\
$\mathbf{4 c}$ & 0.849 & 1.123 & $1.167^{b}$ & 0.044 \\
$\mathbf{4 d}$ & 0.749 & 1.023 & $0.980^{b}$ & -0.043 \\
$\mathbf{4 e}$ & 0.757 & 1.030 & $0.972^{b}$ & -0.058 \\
$\mathbf{4 f}$ & 0.733 & 1.007 & $0.957^{b}$ & -0.050 \\
$\mathbf{4 g}$ & 0.825 & 1.099 & $1.061^{b}$ & -0.038 \\
$\mathbf{4 h}$ & 0.857 & 1.130 & $1.112^{b}$ & -0.018 \\
$\mathbf{4 i}$ & 0.817 & 1.091 & & \\
$\mathbf{4 j}$ & 0.875 & 1.148 & $1.142^{b}$ & -0.006 \\
$\mathbf{4 k}$ & 0.717 & 0.990 & $0.920^{b}$ & -0.070 \\
$\mathbf{5 a}$ & 0.729 & 1.003 & $0.972^{b}$ & -0.031 \\
$\mathbf{5 b}$ & 1.027 & 1.301 & & \\
$\mathbf{6}$ & 0.816 & 1.091 & $0.967^{b}$ & -0.124 \\
$\mathbf{7}$ & 0.793 & 1.067 & $1.042^{b}$ & -0.025
\end{tabular}

Figure 9. Chemical structure of different nitroxide - based radicals alongside with their oxidation potential. ${ }^{[95,96]}$

\section{Organometallic compounds}

Organometallic based materials possess a strong stability and a tunable structure by molecular engineering. Organometallic compounds could be classified in 2 main categories: $\sigma-$ bond and $\pi-$ bond compounds. In the context of this review, we would like to reclassify in 2 families of molecules, i.e. metallocene and metal - organic complexes. An appropriate organometallic compound must satisfy at least 3 main conditions: (1) large redox potential, (2) high solubility and (3) strong stability over long - term cycling.

\subsection{Metal - organic complex}

Carino et al. ${ }^{[98]}$ proposed a complex of 1,2,3,4-tetrahydro-6,7dimethoxy-1,1,4,4-tetramethylnaphthalene (TDT) and $\mathrm{Li}^{+}$as stable catholyte. As active material, TDT could provide a high oxidation potential of $4.21 \mathrm{~V} / \mathrm{Li}+\mid \mathrm{Li}$. However, the stability in the solution causes a major drawback for its use in RFB, resulting from an irreversible degradation. Importantly, it was demonstrated by using normalized in situ Fourier transform infrared spectroscopy (SNFTIRS) coupled with DFT calculation that by coordinating TDT with $\mathrm{Li}+$ via the Lewis basic methoxy function of the neutral TDT, the stability of the molecule is strongly enhanced. This phenomenon could be explained by a reversible complexation (TDT $-\mathrm{Li}^{+}$) and decomplexation (TDT ${ }^{++}$ $+\mathrm{Li}^{+}$) For a counter example, $\mathrm{TBA}^{+}$was used to prevent the formation of TDT complex, leading to very poor stability. Thus, a theoretical energy density is expected at $111 \mathrm{Wh} . \mathrm{I}^{-1}$. Pan et al reported the use of Biphenyl-lithium-TEGDME solution as concentrated $\mathrm{Li}-$ organic solution $(>2 \mathrm{M})^{[99]}$. The $\mathrm{Li}-$ complex would reduce the possible passivation and degradation of $\mathrm{Li}$ metal. The complex exhibits a quasi-reversibility with half wave potential of $0.39 \mathrm{~V} / \mathrm{Li}+\mid \mathrm{Li}$, which is the lowest potential among reported anolyte in the literature. By coupling with a redox targeting system as cathode side, the overall cell voltage is obtained at $3.0 \mathrm{~V}$. However, a sluggish energy efficiency of $56 \%$ was observed after 20 cycles (70\% for the initial cycle) and a moderate coulombic efficiency of $90 \%$ was obtained after 20 cycles. It was claimed that the performance of the cell is constrained by the $\mathrm{Li}$ - ion conducting membrane. After all, the facile procedure for preparing robust and stable alkali complex with high solubility pave the way for developing a high - energy batteries.

\subsection{Metallocene}

Metallocene is the common term to refer to a class of organometallic compounds. They are composed of a transition metal ion placed in sandwich between 2 cyclopentadienyl rings. The bonding between metal center and the rings is ensured by $\pi$ electrons of the cyclopentadienyl rings. In addition, all 10 carbons are equally bonded to the metal ion. It is worth noting that the stability of metallocene depends strongly on the electronic configuration of the metal. For example, cobaltocenium is strongly stable where Co center has the valence electronic shell of preceded noble gas, Kr. For other metallocenes of the first transition row, the filling of the $d$ orbitals splits in 3 molecular orbitals, including $e_{2 g}\left(x^{2}-y^{2}, x y\right)$, $a^{\prime}{ }_{1 g}\left(z^{2}\right)$ and $e^{*}{ }_{1 g}(x z, y z)$ under the influence of the pseudooctahedral field of cyclopentadienyl ligands. As the structure of metallocene is field ligands dependent, the redox potential is contingent on the nature of electrolyte. Electrochemical behaviors of typical metallocenes were reviewed by Kotz et al. ${ }^{[100]}$ and displayed in the table 2 .

Among different metallocenes and related molecules, ferrocene is the most investigated molecules because of its inertness towards oxidative environment. Furthermore, the fast kinetic provided by ferrocene $\left(1 \mathrm{~cm} . \mathrm{s}^{-1}\right)$ and its derivatives becomes a key parameter for their use in $\mathrm{Li}$ - ion redox flow batteries. ${ }^{[101]}$ In addition, the oxidation potential of ferrocene could be modulated 
by functionalizing with electron donating or electron withdrawing group. Typically, a ferrocene bearing imidazolium ring, ${ }^{[102]}$ or quaternary ammonium ${ }^{[103]}$ as EWGs witnesses a positive shift in

Table 2. Standard potential of different metallocene ${ }^{[100]}$. Potentials are reported vs SCE.

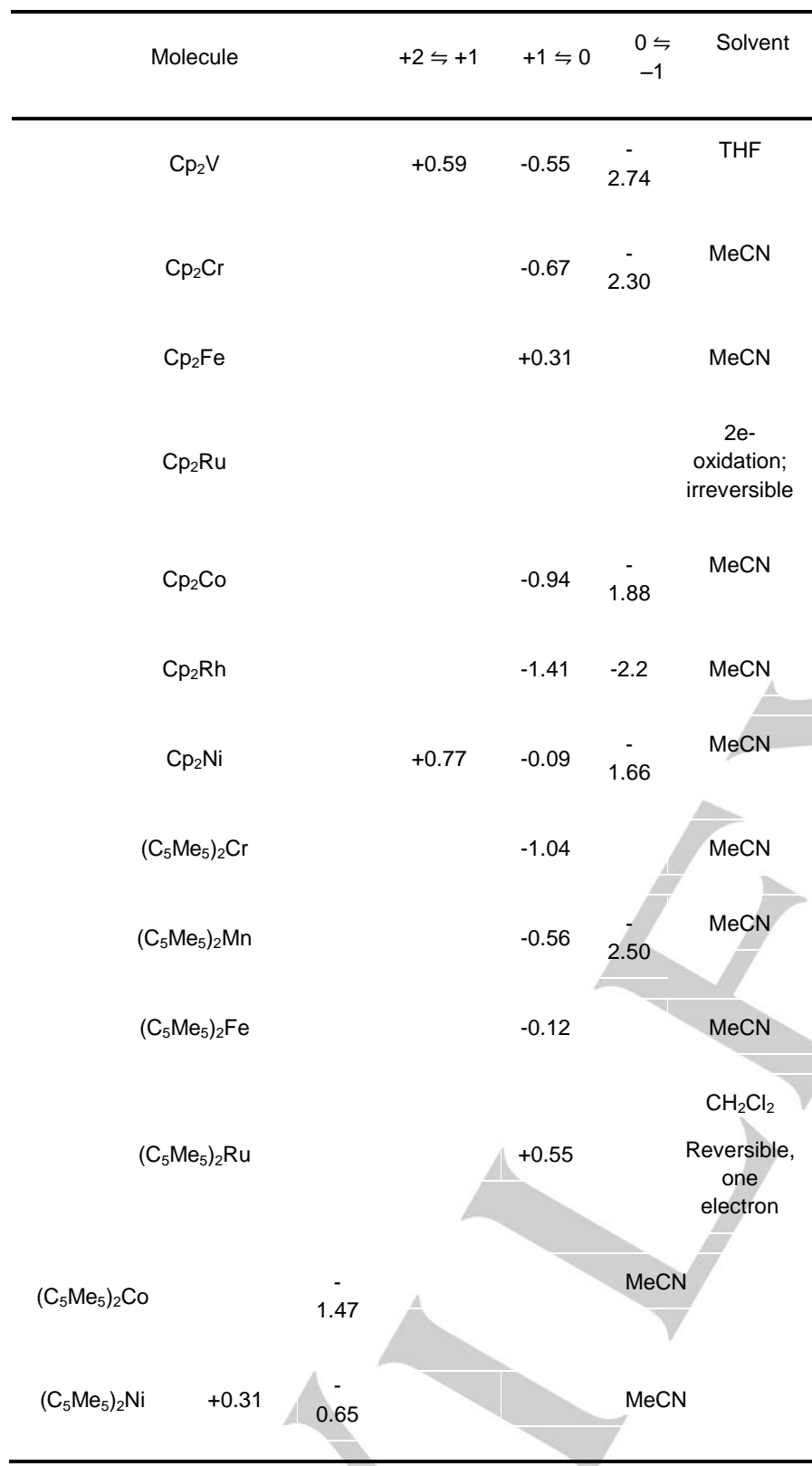

oxidation potential of $150 \mathrm{mV}$ and $220 \mathrm{mV}$, respectively. It is known in the literature that the Fc derivatives could cover a broad range of potential, varying from $-0.12 \mathrm{~V}$ to $0.8 \mathrm{~V} / \mathrm{SCE}$. In parallel, figure 10 described different routes to functionalize ferrocene. Most common approaches could be listed as acylation, carboxylation and lithiation.

Yu's group proposed a series of studies on the potential application of ferrocene derivatives towards RFB. The first demonstration by the group was the use of pristine ferrocene as redox couple for a high power $\mathrm{Li}$ - ion battery. ${ }^{[57]}$ The cell was constructed with $0.1 \mathrm{M}$ of $\mathrm{Fc}$ in $1 \mathrm{M}$ of $\mathrm{LiPF}_{6} / \mathrm{DMF}$. The heterogeneous electron transfer rate constant was calculated for both redox forms $\left(1.2 \times 10^{-2} \mathrm{~cm} . \mathrm{s}^{-1}\right.$ for FC oxidation and $6.3 \times 10$ ${ }^{3}$ for $\mathrm{Fc}^{+}$reduction).

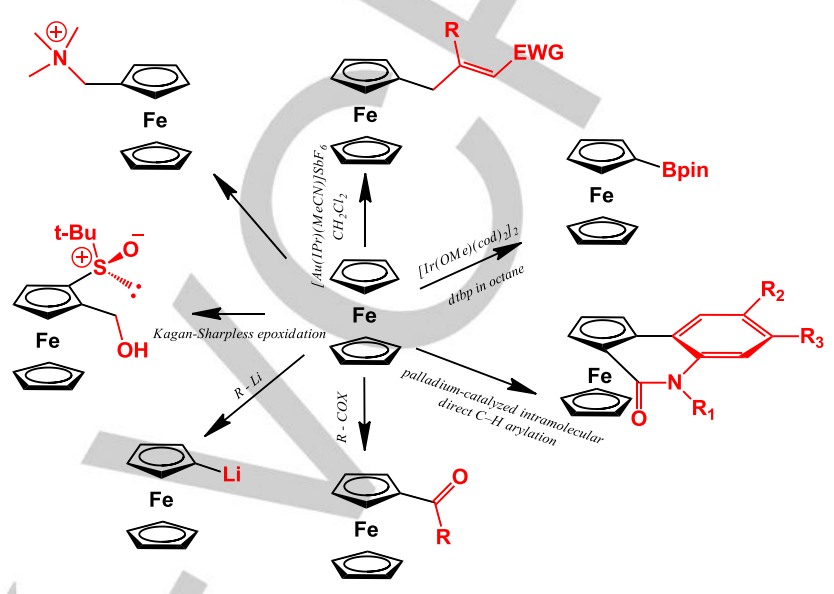

Figure 10. Functionalization routes of ferrocene.

Both values are relatively high compared to other organic/organometallic complexes in aqueous/aprotic solvents, leading to an expectedly high-power density. Consequently, the cell voltage is at $3.5 \mathrm{~V} / \mathrm{Li}^{+} / \mathrm{Li}$ with a specific capacity of 130 mAh. $\mathrm{g}^{-1}$ and the system could deliver $120 \mathrm{~W} . \mathrm{kg}^{-1}$ (Figure 10a). The robustness of the system is also well appreciated with a capacity of $90 \%$ and a CE of $98 \%-100 \%$ after 250 full cycles. Aiming to increase the solubility, i.e. energy density, a ferrocene molecule bearing quaternary ammonium was synthetized and applied as positive electrolyte. ${ }^{[104]}$ Bearing ionic functional group, the solubility of the modified molecules was strongly improved compared to the pristine ferrocene $(1.7 \mathrm{M}$ in the EC/PC/EMC and $\sim 0.85 \mathrm{M}$ in the $1.2 \mathrm{M}$ LiTFSI/EC/PC/EMC). Cycling performance of this molecule was performed using Li|Fc1N112TFSI flow cell $(0.1 \mathrm{M}$ of redox molecule $+1 \mathrm{M}$ LiTFSI with $5 \% \mathrm{wt}$ of FEC). As an important results, the discharged voltage is $~ 3.3$ $\mathrm{V} / \mathrm{Li}^{+} / \mathrm{Li}$ at $3.5 \mathrm{~mA} . \mathrm{cm}^{-2}$ with an energy density of $50 \mathrm{Wh}^{-1}$ (Figure 11b), the coulombic and the energy efficiency were maintained at $99 \%$ and $87 \%$ after 100 cycles. Also, the capacity retention of $99.95 \%$ was obtained. The authors also claimed that the broad and stable voltage window of ferrocene could provide $\mathrm{Li}$ - metal protection, which had been also observed elsewhere. ${ }^{[105]}$ In another study on $\mathrm{FCN}_{4}{ }^{+}$, Cosimbescu and co-workers ${ }^{[106]}$ investigated the influence of the counter anion on the cyclability. Firstly, the solubility is dramatically changed by varying the anion, i.e. ionic Fc having $\mathrm{N}\left(\mathrm{CH}_{2}\right)^{-}$has a solubility of $2.08 \mathrm{M}$ in EC/PC/EMC mixture while the value for $\mathrm{BF}_{4}^{-}$is only $0.4 \mathrm{M}$. All of the molecules were tested in RFB configuration by using $\mathrm{Li}$ metal as anode and the catholyte composed of active molecules and $1.2 \mathrm{M}$ of LiA electrolyte $(\mathrm{A}=$ corresponding anion). The investigated redox molecules results in a cell voltage of $\sim 3.45 \mathrm{~V} / \mathrm{Li}^{+} / \mathrm{Li}$. It was observed that Fc1N112 coupled with $\mathrm{TFSI}^{-}$and $\mathrm{ClO}_{4}{ }^{-}$anions exhibit remarkable stability 
with $88 \%$ and $93 \%$ EE over 250 full cycles. In term of energy

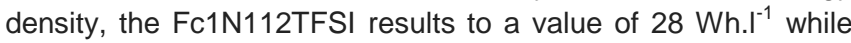
Fc1N112 $\mathrm{ClO}_{4}$ provides only $13 \mathrm{Wh}^{-1}$. The lower energy density of $\mathrm{Fc} 1 \mathrm{~N} 112 \mathrm{ClO}_{4}$ is mainly due to its low solubility $(0.63 \mathrm{M})$. It was also reported that the capacity retention for both systems is very significant $(0.04 \%$ and $0.02 \%$, respectively). For

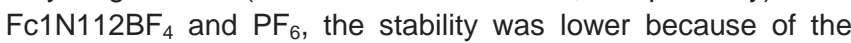
poor solubility of the oxidized forms which are found to precipitate after cycling.
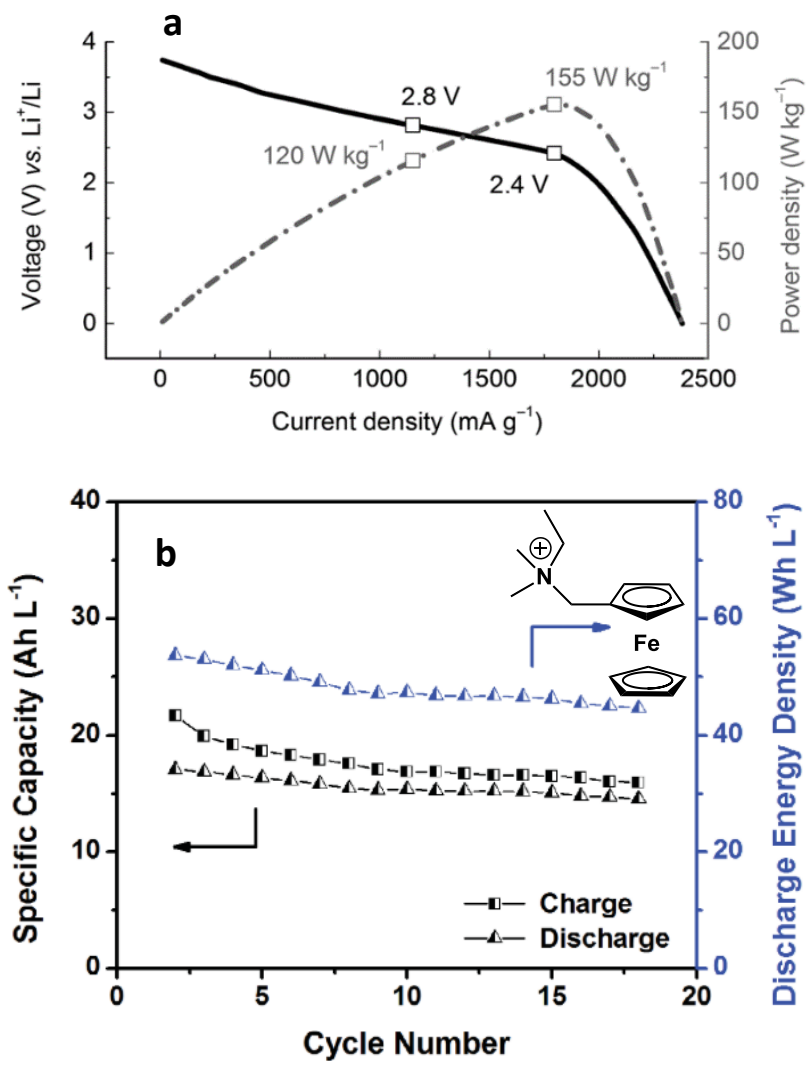

Figure 11. (a) Polarization curve and power density at RT using $\mathrm{Fc}^{+} / \mathrm{Fc}$ as redox couple ${ }^{[57]}$ (b) Volumetric specific capacities and discharge energy densities in function of cycle number of Fc1N112TFSI $(0.8 \mathrm{M}$ in $1.2 \mathrm{M}$ of LiTFSI/ EC/PC/ EMC electrolyte) at $1.5 \mathrm{~mA} . \mathrm{cm}^{-2}{ }^{[106]}$

As aforementioned, Wang and coworkers proposed an innovative approach to combine solid Li storage material and redox mediator via redox targeting reaction..$^{[65,71]}$ As a proof of concept, ferrocene and dibromoferrocene were used to target the standard potential of $\mathrm{LiFePO}_{4}$ as well as cobaltocene and decamethylcobaltocene were used to target anatase $\left(\mathrm{TiO}_{2}\right)$. From the previously described principle, the energy density was determined at 238 Wh. l $^{-1}$ which is among the best performance RFB up - to - date. Recently, to minimize the voltage loss which is mainly due to the difference in standard potential of two redox shuttles (Vloss $(\mathrm{FcBr} 2 / \mathrm{Fc})=300 \mathrm{mV}$ when paired with $\mathrm{LiFePO}_{4}{ }^{\left[{ }^{[65]}\right.}$ Vloss $\left(\mathrm{CoCp} 2^{*} / \mathrm{CoCp}\right)=540 \mathrm{mV}$ for $\mathrm{TiO}_{2}{ }^{[107]}$ ). This work reported the concept of single molecule redox targeting. The main idea of this approach is to use a redox species that has identical standard potential compared to LFP to target the oxidation/reduction of the active material, resulting from Nernst equation. ${ }^{[108]}$ As depicted in Figure 11, the battery operation can be described with two associated events occurring in the cell and tank.

$\mathrm{RM} \leftrightharpoons \mathrm{RM}^{+}+\mathrm{e}^{-}$

$\mathrm{LiFePO}_{4}+\mathrm{RM}^{+} \leftrightharpoons \mathrm{FePO}_{4}+\mathrm{RM}+\mathrm{e}^{-}$

In the cell, a simple electrochemical reaction is necessary for generating oxidized species $\left(\mathrm{RM}^{+}\right)$whereas in the storage tank, the oxidized molecules undergo reversible SMRT reaction to regenerate $\mathrm{RM}$ and delithiate LFP.

The principle of the SMRT reaction is illustrated in Figure 11. Upon charging or discharging, the equilibrium potential of RM (ERM) varies with the activities of the oxidized and reduced states, as governed by the Nernst equation:

$$
\mathrm{E}_{\mathrm{RM}}=\mathrm{E}_{\mathrm{RM}^{+} / \mathrm{RM}}^{0}+\frac{\mathrm{RT}}{\mathrm{F}} \ln \frac{\mathrm{a}_{\mathrm{RM}^{+}}}{\mathrm{a}_{\mathrm{RM}}}
$$

Then, the difference of potential between the molecule and the solid material, provides driving force for the reaction previously described. To validate the SMRT reactions, the 1Ferrocenylmethyl-3-methylimidazolium TFSI was chosen as mediator (3.43 V/E $\mathrm{Li}+/ \mathrm{Li})$, affording very good fit with the standard potential of LFP. Moreover, the FcIL offers higher solubility, beyond $1.45 \mathrm{M}$ in carbonated based electrolyte than pristine $\mathrm{FC}$ $(<0.2 \mathrm{M})$. When $0.44 \mathrm{M}$ equivalent $\mathrm{LiFePO}_{4}$ powder was introduced into the cathodic compartment, the static cell revealed an extended voltage plateau beyond the capacity of $0.50 \mathrm{M} \mathrm{FclL}$ in the catholyte. Distinct from the previously reported two-molecule redox systems ${ }^{[65]}$ or single molecule with multiple redox potentials,${ }^{[69,70]}$ the cell exhibits only one voltage plateau, which considerably eliminates the voltage loss and thus unprecedentedly improves the voltage efficiency to about $95 \%$. Benefitting from the SMRT reaction, the flow cell exhibited voltage efficiency over $94 \%$, which is on a par with or even superior to other rival battery technologies. The Coulombic efficiency was around $90 \%$ for the flow cell, which is presumably due to the crossover of redox molecules upon prolonged test as a slight color change of the anolyte after disassembling the cell. Because the FclL stays in a reduced state in anolyte, it would remain intact upon cycling. To eliminate the adverse effect of crossover, the same electrolyte composition in both the anolyte and catholyte could be used to reduce the concentration gradient and thus crossover. With the same electrolyte, the cycling stability of the flow cell was tested at controlled capacity, which shows Coulombic efficiency $>97 \%$ and negligible degradation over 50 cycles, revealing the robustness of the SMRT system. 
As a proof-of-concept study, the tank energy density of the flow

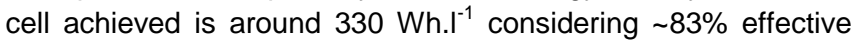
porosity of the solid material in the tank with reachable energy density of 942 Wh. $\mathrm{l}^{-1}$. For instance, only ferrocene derivatives have been widely exploited in redox flow batteries which is resulted from their superior stability in electrochemical tests. Even though other metallocenes have already been explored, there use in RFB still limited. This result is due to their instability during synthesis and electrochemical measurements. Nevertheless, from structural standpoint, it could be possible to stabilize these molecules by substituting the hydrogen from the cyclopentadienyl rings by other functional groups. Accordingly, the success of this effort could pave the way for a larger choice of metallocene in RFB configuration.
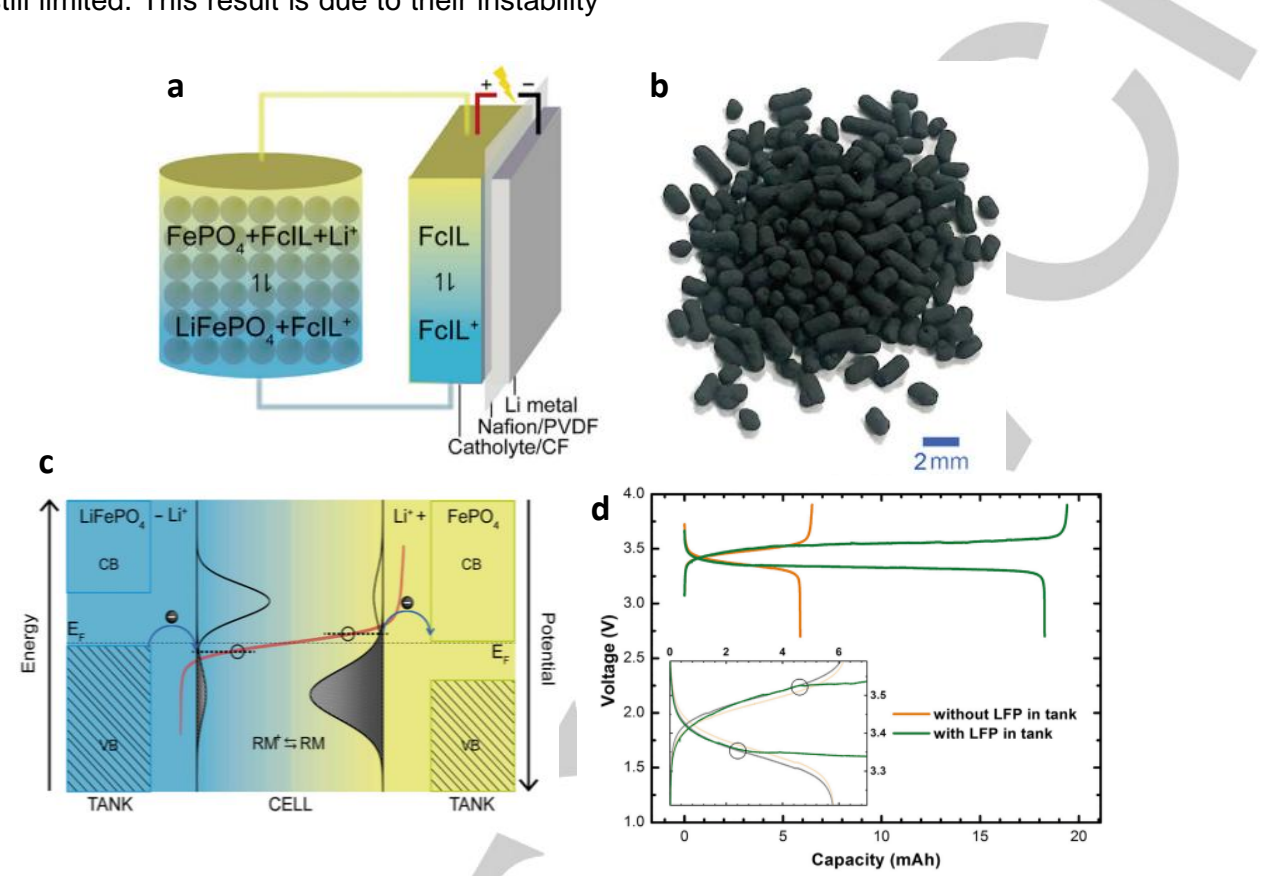

Figure 12. Working Principle of the Single-Molecule Redox-Targeting (SMRT) Reaction. (a) Schematic presentation of an RFB half - cell, (b) LFP granules, (c) Energy diagram and charge transfer of the SMRT reactions of RM+ with LiFePO4 upon charging and RM with FePO4 upon discharging. The thick dashed line marks the formal potential of RM/RM+, and the thin dashed line indicates the Fermi level of solid material. (d) Voltage profiles of flow cells with $0.20 \mathrm{M}$ FclL in the catholyte and $0.37 \mathrm{M}$ equivalent $\mathrm{LiFePO} 4$ granules in the tank. ${ }^{[108]}$

\section{Concluding remarks and outlook}

A key parameter in developing redox flow batteries for stationary large-scale energy storage is enhancing the energy density. As summarized in this review, several approaches have been proposed to improve either the solubility of the redox mediator and the cell voltage. Commonly, 3 main categories of redox molecules have been reported, including electron donor, electron acceptor and bipolar molecules. Although numerous $n$ type molecules have been developed, multiple major issues related to their solubility and stability over cycling are still remained open for further investigations. Indeed, organic and most of organometallic compounds undergo irreversible structural rearrangement and/or bond cleavage that conduct to uncertainties in proposed reaction mechanism. Common problem could be the electronic stress during electro-oxidation/ reduction that results to chemical bond reconstruction. Accordingly, one of major challenges in development of organic redox mediators consists to design stress - tolerant electroactive centers, i.e. the molecules are stabilized by means of extended electronic delocalization without brutal bond rearrangement, which could be compromised with the desired standard potential. Even though it is still irresolute in the literature, a real tendency could obviously observe where charged nitrogen contained molecules (quaternary ammonium, imidazolium, etc.) exhibit greater stability and durability. Besides, there is a real discrepancy in reported solubility of active molecules. From energy capacity standpoint, the latter point could reveal a significant problem. Consequently, a relevant guideline in characterizing of such system needs to be generated and followed in a systematic way. Finally, the understanding of interactions between redox mediators and electrolytes is still scanty. These interactions could eventually result to the self-aggregation, the passivation of the electrode or even to the degradation of the active materials. Up to date, the molecules that exhibit a better compromise between good performance and reasonable solubility and cyclability are among quinone derivatives. By replacing some hydrogen from the aromatic rings by functional groups, the cell voltage could reach $\sim 3.5 \mathrm{~V} / \mathrm{Li}^{+} / \mathrm{Li}$ with an energy density of $\sim 25 \mathrm{Wh} . \mathrm{I}^{-1}$. Concerning 
p-type molecules, they have not been intensively explored, resulting to very few investigated compounds. For organic $\mathrm{Li}-$ ion RFB, the most promising compounds seems to be bipolar molecules, with TEMPO as typical example. They exhibit high solubility with strong stability over cycling. Furthermore, energy

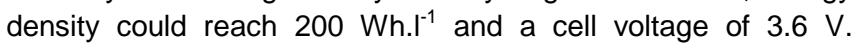
However, a large variety of structures are remained unexplored. Other choices rely on a wide range of organometallic complexes with robust structure during electron transfer events. As a key parameter, metallocenes have in particular very high electron transfer kinetic, leading to high power LRFB. In parallel with a conventional use as active materials in anolyte or catholyte, they could be used as redox shuttles for targeting solid Li material, leading to remarkably high energy density batteries. The highest performance is attributed to a single molecule redox targeting (SMRT) using a ferrocene bearing imidazolium ring as redox mediator for LFP. The obtained energy density could reach 942 Wh. $I^{-1}$. The future prospect of this sub-field is mainly based on the molecular engineering, affording appropriate structure with higher solubility in common electrolyte, a strong stability over cycling. Also, the electron transfer kinetic of organic molecules needs to be improved.

Keywords: redox flow batteries, redox targeting, organic redox shuttles, molecular design.

\section{Acknowledgments:}

This international collaboration is supported by the Universite'Sorbonne Paris Cite (USPC) - National University of Singapore (NUS) Alliance 2015. 
Hyacinthe Randriamahazaka is full Professor at Université de Paris. He obtained his $\mathrm{PhD}$ in physical chemistry in 1991 at Université François Rabelais of Tours, France. He leads a research group SIELE (Surfaces - lonic liquids ELectrochemistry - Energy) within ITODYS laboratory (CNRS UMR 7086). His major research interest is in understanding the electrodeposition and electrografting processes, the photoelectrochemical processes, the heterogeneous electron transfer mechanisms, the charge transfer within organic and carbon based materials, and modelling. These studies focused on the development of various electrochemical devices (supercapacitors, artificial photosynthesis, electrocatalysis, redox-flow batteries, actuators, and nanogenerators).

Jalal Ghilane received his Master's degree in electrochemistry from University of Paris Diderot in 2002. In 2005 he obtained a PhD degree in physical chemistry at the University of Rennes 1. From 2005 to 2007 he was a postdoctoral fellowship in Professor Allen J. Bard groups at the University of Texas in Austin (United States). Since 2007 he joined the CNRS as Research Fellow at Université de Paris. His current scientific interests focused on nanoscale electrochemistry and scanning electrochemical microscopy, surface grafting, polymer ionic liquids, and electro-catalysis.
Thuan-Nguyen Pham-Truong is Associate Professor at Cergy - Pontoise University (France) from 2019. He obtained his $\mathrm{PhD}$ in Physical Chemistry in November 2018 from Université Paris Diderot, France. Then, he continued his research with a short postdoctoral training in the group of Prof. Allen J. Bard at University of Texas at Austin, USA. His current research interest includes the development of functional materials for energy and environmental driven applications

Qing Wang is an Associate Professor at the Department of Materials Science and Engineering, National University of Singapore. He obtained his Ph.D. in physics at the Institute of Physics, Chinese Academy of Sciences in 2002. Currently, he is leading a research group to conduct fundamental and applied studies on charge transport in mesoscopic energy conversion and storage systems, including the redoxtargeting-based flow batteries for large-scale energy storage.
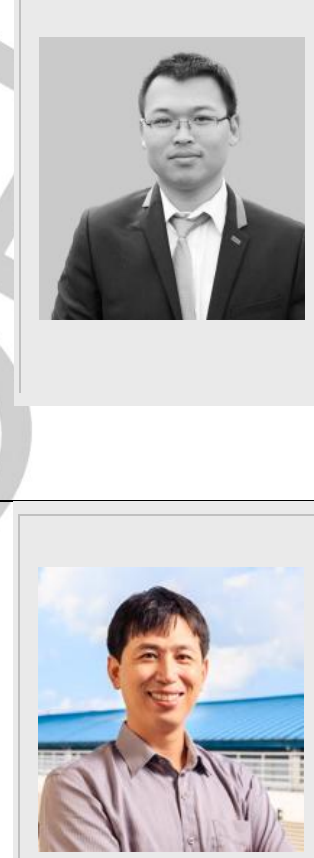


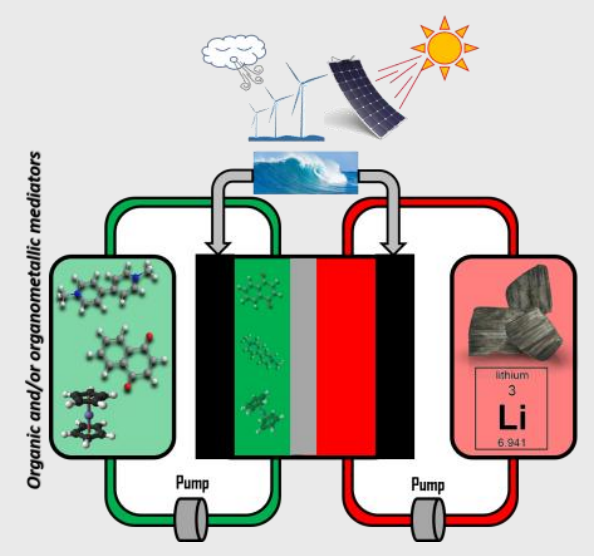

Thuan-Nguyen Pham-Truong, Qing Wang, Jalal Ghilane* and Hyacinthe Randriamahazaka*

Page No.1 - Page No.20

Recent advances in development of organic and organometallic redox shuttles for lithium-ion redox flow batteries 
[1] K. Mizushima, P. C. Jones, P. J. Wiseman, J. B. Goodenough, Mater. Res. Bull. 1980, 15, 783789.

[2] C. Masquelier, A. K. Padhi, K. S. Nanjundaswamy, J. B. Goodenough, J. Solid State Chem. 1998, 135, 228-234.

[3] P. L. Taberna, S. Mitra, P. Poizot, P. Simon, J. M. Tarascon, Nat. Mater. 2006, 5, 567-573.

[4] L. X. Yuan, Z. H. Wang, W. X. Zhang, X. L. Hu, J. T. Chen, Y. H. Huang, J. B. Goodenough, Energy Environ. Sci. 2011, 4, 269-284.

[5] B. Guo, X. Yu, X. G. Sun, M. Chi, Z. A. Qiao, J. Liu, Y. S. Hu, X. Q. Yang, J. B. Goodenough, S. Dai, Energy Environ. Sci. 2014, 7, 2220-2226.

[6] J. M. Tarascon, Philos. Trans. R. Soc. A Math. Phys. Eng. Sci. 2010, 368, 3227-3241.

[7] A. Manthiram, J. Phys. Chem. Lett. 2011, 2, 176-184.

[8] N. S. Choi, Z. Chen, S. A. Freunberger, X. Ji, Y. K. Sun, K. Amine, G. Yushin, L. F. Nazar, J. Cho, P. G. Bruce, Angew. Chemie - Int. Ed. 2012, 51, 9994-10024.

[9] D. Deng, Energy Sci. Eng. 2015, 3, 385-418.

[10] R. Ferrigno, A. D. Stroock, T. D. Clark, M. Mayer, G. M. Whitesides, J. Am. Chem. Soc. 2002, $124,12930-1$.

[11] W. A. Braff, M. Z. Bazant, C. R. Buie, Nat. Commun. 2013, 4:2346, 1-6.

[12] P. K. Leung, T. Martin, A. A. Shah, M. A. Anderson, J. Palma, Chem. Commun. 2016, 52, 14270-14273.

[13] M. Bartolozzi, J. Power Sources 1989, 27, 219-234.

[14] W. Lumen, G. Degner, Minute Epics of Flight, Grosset \& Dunlap, New York, 1933.

[15] A. M. Posner, Fuel 1955, 34, 330-338.

[16] NASA Lewis Research Center, NASA-TM-79067 - DOE/NASA/1002-78/2, 1979.

[17] NASA Lewis Research Center, NASA-TM-81464 - DOE/NASA/1002-80/5, 1980.

[18] NASA Lewis Research Center, NASA-TM-82607 - DOE/NASA/12726-8, 1981.

[19] Charles River Associates Inc, NASA-CR-167882 - DOE/NASA/0251-1 - NAS 1.26:167882, 1982.

[20] NASA Lewis Research Center, NASA-TM-82686 - DOE/NASA/12726-11, 1982.

[21] NASA Lewis Research Center, NASA-TM-82940 - E-1340, DOE/NASA/12726-18 - NAS 1.15:82940, 1982.

[22] NASA Lewis Research Center, NASA-TM-83401 - E-1679, DOE/NASA/12726-22 - NAS 1.15:83401, 1983.

[23] M. Rychcik, M. J. Skyllas - Kazacos, J. Power Sources 1988, 22, 59-67.

[24] M. Skyllas-Kazacos, R. Robins, M. Rychick, All-Vanadium Redox Battery, 1986, Japan Patent 2724817.

[25] M. Skyllas-Kazacos, M. Rychcik, R. Robins, All-Vanadium Redox Battery, 1986, AU Patent 575247.

[26] M. Skyllas-Kazacos, M. Rychick, R. Robins, All-Vanadium Redox Battery, 1988, US4786567A.

[27] X. Li, H. Zhang, Z. Mai, H. Zhang, I. Vankelecom, Energy Environ. Sci. 2011, 4, 1147-1160.

[28] A. Parasuraman, T. M. Lim, C. Menictas, M. Skyllas-Kazacos, Electrochim. Acta 2013, 101, 2740.

[29] B. Sun, M. Skyllas-Kazacos, Electrochim. Acta 1992, 37, 1253-1260.

[30] J. Xi, Z. Wu, X. Qiu, L. Chen, J. Power Sources 2007, 166, 531-536.

[31] J. Heo, J. Han, S. Kim, S. Yuk, C. Choi, R. Kim, J. Lee, A. Klassen, S. Ryi, H. Kim, Nat. Commun. 2019, 10, 1-9.

[32] Y. Xu, Y. Wen, J. Cheng, G. Cao, Y. Yang, Electrochem. commun. 2009, 11, 1422-1424.

[33] Y. Xu, Y. H. Wen, J. Cheng, G. P. Cao, Y. S. Yang, Electrochim. Acta 2010, 55, 715-720.

[34] B. Huskinson, M. P. Marshak, C. Suh, S. Er, M. R. Gerhardt, C. J. Galvin, X. Chen, A. AspuruGuzik, R. G. Gordon, M. J. Aziz, Nature 2014, 505, 195-198.

[35] K. Wedege, J. Azevedo, A. Khataee, A. Bentien, A. Mendes, Angew. Chemie - Int. Ed. 2016, 55, 
$7142-7147$.

[36] S. E. Doris, A. L. Ward, A. Baskin, P. D. Frischmann, N. Gavvalapalli, E. Chénard, C. S. Sevov,

D. Prendergast, J. S. Moore, B. A. Helms, Angew. Chemie - Int. Ed. 2017, 56, 1595-1599.

[37] F. R. Brushett, J. T. Vaughey, A. N. Jansen, Adv. Energy Mater. 2012, 2, 1390-1396.

[38] X. Wei, W. Xu, J. Huang, L. Zhang, E. Walter, C. Lawrence, M. Vijayakumar, W. A. Henderson,

T. Liu, L. Cosimbescu, et al., Angew. Chemie - Int. Ed. 2015, 54, 8684-8687.

[39] T. Liu, X. Wei, Z. Nie, V. Sprenkle, W. Wang, Adv. Energy Mater. 2016, 6, 1501449

[40] K. Lin, Q. Chen, M. R. Gerhardt, L. Tong, S. B. Kim, L. Eisenach, A. W. Valle, D. Hardee, R. G. Gordon, M. J. Aziz, et al., Science (80-. ). 2015, 349, 1529-1532.

[41] M. A. Goulet, L. Tong, D. A. Pollack, D. P. Tabor, S. A. Odom, A. Aspuru-Guzik, E. E. Kwan, R. G. Gordon, M. J. Aziz, J. Am. Chem. Soc. 2019, 8-13.

[42] B. Hu, J. Luo, M. Hu, B. Yuan, T. L. Liu, Angew. Chemie Int. Ed. 2019, 2-10.

[43] S. Er, C. Suh, M. P. Marshak, A. Aspuru-Guzik, Chem. Sci. 2015, 6, 885-893.

[44] Y. Zhao, S. Si, C. Liao, J. Power Sources 2013, 241, 449-453.

[45] E. Zanzola, C. R. Dennison, A. Battistel, P. Peljo, H. Vrubel, V. Amstutz, H. H. Girault, Electrochim. Acta 2017, 235, 664-671.

[46] S. H. Oh, C. W. Lee, D. H. Chun, J. D. Jeon, J. Shim, K. H. Shin, J. H. Yang, J. Mater. Chem. A 2014, 2, 19994-19998.

[47] T. Janoschka, N. Martin, U. Martin, C. Friebe, S. Morgenstern, H. Hiller, M. D. Hager, U. S. Schubert, Nature 2015, 527, 78-81.

[48] C. DeBruler, B. Hu, J. Moss, X. Liu, J. Luo, Y. Sun, T. L. Liu, Chem 2017, 3, 961-978.

[49] Y. Liu, M. A. Goulet, L. Tong, Y. Liu, Y. Ji, L. Wu, R. G. Gordon, M. J. Aziz, Z. Yang, T. Xu, Chem 2019, 5, 1861-1870.

[50] J. Winsberg, C. Stolze, S. Muench, F. Liedl, M. D. Hager, U. S. Schubert, ACS Energy Lett. 2016, 1, 976-980.

[51] X. Wei, W. Xu, M. Vijayakumar, L. Cosimbescu, T. Liu, V. Sprenkle, W. Wang, Adv. Mater. 2014, 26, 7649-7653.

[52] J. Huang, L. Su, J. A. Kowalski, J. L. Barton, M. Ferrandon, A. K. Burrell, F. R. Brushett, L. Zhang, J. Mater. Chem. A 2015, 3, 14971-14976.

[53] Y.-W. D. Chen, K. S. V. Santhanam, A. J. Bard, J. Electrochem. Soc. 1981, 128, 1460-1467.

[54] D. G. Kwabi, K. Lin, Y. Ji, E. F. Kerr, M. A. Goulet, D. De Porcellinis, D. P. Tabor, D. A. Pollack, A. Aspuru-Guzik, R. G. Gordon, et al., Joule 2018, 2, 1894-1906.

[55] J. Luo, A. Sam, B. Hu, C. DeBruler, X. Wei, W. Wang, T. L. Liu, Nano Energy 2017, 42, 215221.

[56] Z. Yang, L. Tong, D. P. Tabor, E. S. Beh, M. A. Goulet, D. De Porcellinis, A. Aspuru-Guzik, R. G. Gordon, M. J. Aziz, Adv. Energy Mater. 2018, 8, 1-9.

[57] Y. Zhao, Y. Ding, J. Song, G. Li, G. Dong, J. B. Goodenough, G. Yu, Angew. Chemie - Int. Ed. 2014, 53, 11036-11040.

[58] B. Hwang, M. S. Park, K. Kim, ChemSusChem 2015, 8, 310-314.

[59] Y. Ding, Y. Zhao, Y. Li, J. B. Goodenough, G. Yu, Energy Environ. Sci. 2017, 10, 491-497.

[60] Y. Lu, J. B. Goodenough, Y. Kim, J. Am. Chem. Soc. 2011, 133, 5756-5759.

[61] J. B. Goodenough, Y. Kim, J. Power Sources 2011, 196, 6688-6694.

[62] Y. Lu, J. B. Goodenough, J. Mater. Chem. 2011, 21, 10113-10117.

[63] Y. Wang, Y. Wang, H. Zhou, ChemSusChem 2011, 4, 1087-1090.

[64] Y. Wang, P. He, H. Zhou, Adv. Energy Mater. 2012, 2, 770-779.

[65] Q. Huang, H. Li, M. Grätzel, Q. Wang, Phys. Chem. Chem. Phys. 2013, 15, 1793-1797.

[66] C. Jia, F. Pan, Y. G. Zhu, Q. Huang, L. Lu, Q. Wang, Sci. Adv. 2015, 1, 1-8.

[67] H. Pan, X. Wei, W. A. Henderson, Y. Shao, J. Chen, P. Bhattacharya, J. Xiao, J. Liu, Adv. Energy Mater. 2015, 5, 1-7.

[68] L. Fan, C. Jia, Y. G. Zhu, Q. Wang, ACS Energy Lett. 2017, 2, 615-621. 
[69] Y. G. Zhu, Y. Du, C. Jia, M. Zhou, L. Fan, X. Wang, Q. Wang, J. Am. Chem. Soc. 2017, 139, 6286-6289.

[70] Q. Huang, J. Yang, C. B. Ng, C. Jia, Q. Wang, Energy Environ. Sci. 2016, 9, 917-921.

[71] C. Jia, F. Pan, Y. G. Zhu, Q. Huang, L. Lu, Q. Wang, Sci. Adv. 2015, 1, 1-8.

[72] Y. Zhu, F. Yang, Z. Niu, H. Wu, Y. He, H. Zhu, J. Ye, Y. Zhao, X. Zhang, J. Power Sources 2019, 417, 83-89.

[73] C. Zhang, Y. Qian, Y. Ding, L. Zhang, X. Guo, Y. Zhao, G. Yu, Angew. Chemie - Int. Ed. 2019, $58,7045-7050$.

[74] H. Senoh, M. Yao, H. Sakaebe, K. Yasuda, Z. Siroma, Electrochim. Acta 2011, 56, 1014510150.

[75] W. Wang, W. Xu, L. Cosimbescu, D. Choi, L. Li, Z. Yang, Chem. Commun. 2012, 48, 66696671.

[76] Y. Ding, Y. Li, G. Yu, Chem 2016, 1, 790-801.

[77] Y. Liang, P. Zhang, J. Chen, Chem. Sci. 2013, 4, 1330-1337.

[78] D. S. Shin, M. Park, J. Ryu, I. Hwang, J. K. Seo, K. Seo, J. Cho, S. Y. Hong, J. Mater. Chem. A 2018, 6, 14761-14768.

[79] T. Matsunaga, T. Kubota, T. Sugimoto, M. Satoh, Chem. Lett. 2011, 40, 750-752.

[80] C. S. Sevov, R. E. M. Brooner, E. Chénard, R. S. Assary, J. S. Moore, J. Rodríguez-López, M. S. Sanford, J. Am. Chem. Soc. 2015, 137, 14465-14472.

[81] L. Li, H. X. Gong, D. Y. Chen, M. J. Lin, Chem. - A Eur. J. 2018, 24, 13188-13196.

[82] L. Li, Y. J. Hong, D. Y. Chen, M. J. Lin, Chem. - A Eur. J. 2017, 23, 16612-16620.

[83] L. Li, Y. J. Hong, D. Y. Chen, M. J. Lin, Electrochim. Acta 2017, 254, 255-261.

[84] D. Chen, A. J. Avestro, Z. Chen, J. Sun, S. Wang, M. Xiao, Z. Erno, M. M. Algaradah, M. S. Nassar, K. Amine, et al., Adv. Mater. 2015, 27, 2907-2912.

[85] D. J. Kim, K. R. Hermann, A. Prokofjevs, M. T. Otley, C. Pezzato, M. Owczarek, J. F. Stoddart, J. Am. Chem. Soc. 2017, 139, 6635-6643.

[86] L. Li, Y. J. Hong, D. Y. Chen, W. C. Xiao, M. J. Lin, Chem. Commun. 2019, 55, 2364-2367.

[87] J. Huang, B. Pan, W. Duan, X. Wei, R. S. Assary, L. Su, F. R. Brushett, L. Cheng, C. Liao, M. S. Ferrandon, et al., Sci. Rep. 2016, 6, 1-9.

[88] C. S. Sevov, S. K. Samaroo, M. S. Sanford, Adv. Energy Mater. 2017, 7, 1-5.

[89] C. G. Armstrong, K. E. Toghill, Electrochem. commun. 2018, 91, 19-24.

[90] T. Janoschka, M. D. Hager, U. S. Schubert, Adv. Mater. 2012, 24, 6397-6409.

[91] N. Pan, J. Ling, R. Zapata, J.-P. Pulicani, L. Grimaud, M. R. Vitale, Green Chem. 2019, 21, 6194-6199.

[92] R. A. Green, J. T. Hill-cousins, R. C. D. Brown, D. Pletcher, S. G. Leach, Electrochim. Acta 2013, 113, 550-556.

[93] J. E. Nutting, M. Rafiee, S. S. Stahl, Chem. Rev. 2018, 118, 4834-4885.

[94] T. Suga, Y. J. Pu, K. Oyaizu, H. Nishide, Bull. Chem. Soc. Jpn. 2004, 77, 2203-2204.

[95] D. P. Hickey, D. A. Schiedler, I. Matanovic, P. V. Doan, P. Atanassov, S. D. Minteer, M. S. Sigman, J. Am. Chem. Soc. 2015, 137, 16179-16186.

[96] J. P. Blinco, J. L. Hodgson, B. J. Morrow, J. R. Walker, G. D. Will, M. L. Coote, S. E. Bottle, J. Org. Chem. 2008, 73, 6763-6771.

[97] K. Takechi, Y. Kato, Y. Hase, Adv. Mater. 2015, 27, 2501-2506.

[98] E. V. Carino, J. Staszak-Jirkovsky, R. S. Assary, L. A. Curtiss, N. M. Markovic, F. R. Brushett, Chem. Mater. 2016, 28, 2529-2539.

[99] F. Pan, J. Yang, C. Jia, H. Li, Q. Wang, J. Energy Chem. 2018, 27, 1362-1368.

[100] J. C. Kotz, in Top. Org. Electrochem. (Ed.: B. W.E.), Springer US, Boston, 1986.

[101] O. Fontaine, C. Lagrost, J. Ghilane, P. Martin, G. Trippé, C. Fave, J. C. Lacroix, P. Hapiot, H. N. Randriamahazaka, J. Electroanal. Chem. 2009, 632, 88-96.

[102] T. N. Pham-Truong, F. Lafolet, J. Ghilane, H. Randriamahazaka, Electrochem. commun. 2016, 
$70,13-17$.

[103] T. N. P. Truong, H. Randriamahazaka, J. Ghilane, Electrochem. commun. 2017, 82, 25-29.

[104] X. Wei, L. Cosimbescu, W. Xu, J. Z. Hu, M. Vijayakumar, J. Feng, M. Y. Hu, X. Deng, J. Xiao, J. Liu, et al., Adv. Energy Mater. 2015, 5, 1-7.

[105] N. M. Golovin, P. Wilkinson, David, J. T. Dudley, D. Holonko, S. Woo, J. Electrochem. Soc. 1992, 139, 305-312.

[106] L. Cosimbescu, X. Wei, M. Vijayakumar, W. Xu, M. L. Helm, S. D. Burton, C. M. Sorensen, J. Liu, V. Sprenkle, W. Wang, Sci. Rep. 2015, 5, 1-9.

[107] F. Pan, J. Yang, Q. Huang, X. Wang, H. Huang, Q. Wang, Adv. Energy Mater. 2014, 4, 1-7.

[108] M. Zhou, Q. Huang, T. N. Pham Truong, J. Ghilane, Y. G. Zhu, C. Jia, R. Yan, L. Fan, H. Randriamahazaka, Q. Wang, Chem 2017, 3, 1036-1049. 